\title{
25. THE NEOGENE AND QUATERNARY DIATOM BIOSTRATIGRAPHY OF SUBANTARCTIC SEDIMENTS, DEEP SEA DRILLING PROJECT LEG 71 ${ }^{1}$
}

\author{
Paul F. Ciesielski, University of Georgia, Athens, Georgia
}

\begin{abstract}
Subantarctic sediments recovered in the Southwest Atlantic during Leg 71 provide well-preserved and often diverse assemblages of diatoms representing much of the upper middle Miocene to Holocene. The magnetostratigraphic record of two hydraulic piston core (HPC) sites with high sediment accumulation rates, Sites 512 and 514, is used to establish precise absolute ages for the boundaries of all but three of 15 biostratigraphic zones used to define the upper middle Miocene to Holocene; ages of the remaining three zones are defined by means of piston cores. Of the fifteen zones identified, two are upper middle Miocene to upper Miocene, one brackets the Miocene/Pliocene boundary, and thirteen are Pliocene to Holocene. The existing antarctic-subantarctic Pliocene to Holocene diatom zonation of Weaver and Gombos is revised and further subdivided: five existing zones are revised, and five new zones described. Taxonomic notes on all species studied are presented and several new taxa are proposed.
\end{abstract}

\section{INTRODUCTION}

Leg 71 of the Deep Sea Drilling Project rotary drilled or hydraulic piston cored four sites in subantarctic areas of the Southwest Atlantic Ocean (Fig. 1). Two sites are located on the Falkland Plateau, Site 511 in the basin province of the Plateau and Site 512 on the northeastern part of the Maurice Ewing Bank. Sites 513 and 514 are located on the lower west flank of the Mid-Atlantic Ridge, east of the Argentine Basin. Sites 511 and 512 lie within the present-day Antarctic Convergence Zone (Gordon et al., 1977); whereas Sites 513 and 514 are positioned approximately 240 and $400 \mathrm{~km}$, respectively, north of the Antarctic Convergence.

Deep Sea Drilling Project Leg 71 was the fifth cruise of the Glomar Challenger to the southern high latitudes. Three of the previous cruises were to the Pacific sector of the Southern Ocean: Legs 28 and 29 went to the Southwest Pacific and Leg 35 to the Southeast Pacific. The fourth high-latitude cruise, Leg 36 , drilled in the Southwest Atlantic Ocean, on or near the Falkland Plateau.

Biostratigraphic studies of diatoms recovered by these previous DSDP cruises have resulted in the establishment of zonal schemes for most of the Tertiary; these studies were by McCollum (1975, Leg 28), Hajos (1976, Leg 29), Schrader (1976, Legs 35 and 29, Site 278), and Gombos (1977, Leg 36).

McCollum (1975) established the first detailed diatom zonation of the Neogene and Quaternary, based on his analysis of Leg 28 drill cores and selected Eltanin piston cores. Weaver and Gombos (1981) made a thorough comparison and summary of existing Neogene and Quaternary biostratigraphic data from the Southern Ocean and proposed a regional Neogene diatom zonation based on easily recognizable species with broad

${ }^{1}$ Ludwig, W. J., Krasheninnikov, V. A., et al., Init. Repts. DSDP, 71: Washington (U.S. Govt. Printing Office). geographic distribution. The zonation of Weaver and Gombos (1981) contains 16 biostratigraphic zones, 5 as originally defined by McCollum (1975), 6 modified zones of McCollum (1975) and Schrader (1976), and 5 new zones.

In the present study, the upper middle MioceneHolocene portion of the diatom zonation of Weaver and Gombos (1981) is revised and new zones added to increase biostratigraphic resolution. Particular emphasis is placed on determining the absolute age of all zonal boundaries. Absolute age determinations are based largely on the paleomagnetic record of HPC Sites 512 and 514.

\section{PREPARATION OF SAMPLES AND METHOD OF STUDY}

All samples used in this study were collected by the author during Leg 71. A total of 172 samples were processed for shore-based investigations using the following technique. Raw samples were placed in 200 $\mathrm{ml}$ beakers and heated with diluted hydrogen peroxide to disassociate the sediment and remove the organic carbon. Hydrochloric acid was then added to dissolve any carbonate present in the samples. The undissolved residues were diluted with distilled water, centrifuged, and decanted to remove the acid. This procedure was repeated three times. Next, the samples were washed with sodium pyrophosphate, centrifuged, and decanted to remove a significant proportion of the clay present in the samples. This final processing step was repeated until the sediment suspension obtained a neutral $\mathrm{pH}$. Processed residues were diluted with distilled water and stored in 50-ml plastic bottles.

Strewn slides were prepared of all samples in the following manner. Bottles containing the sediment and water were shaken until all sediment was in solution and a small amount of the suspension was pipetted from the middle of the bottle. A few drops of the pipetted solution were placed on a slide and dispersed uniformly. After drying, cover slips were mounted using Hyrax (n.d. $=1.71)$ as the mounting medium.

Selected samples were sieved after preparation of the whole fraction slides in order to concentrate diatoms and eliminate the clay fraction of the sediment. The sieve size used varied with sediment type and was either $38 \mu \mathrm{m}, 45 \mu \mathrm{m}$, or $63 \mu \mathrm{m}$, or a combination of the three sizes. Slides were prepared of all sieved fractions; those intervals where sieved fractions were examined are indicated in the species occurrence tables by an asterisk beside the interval designations. Sieved fractions were examined to delineate species ranges more accurately. For a more detailed discussion of the advantage of this technique the reader is referred to Gombos and Ciesielski (this volume). 


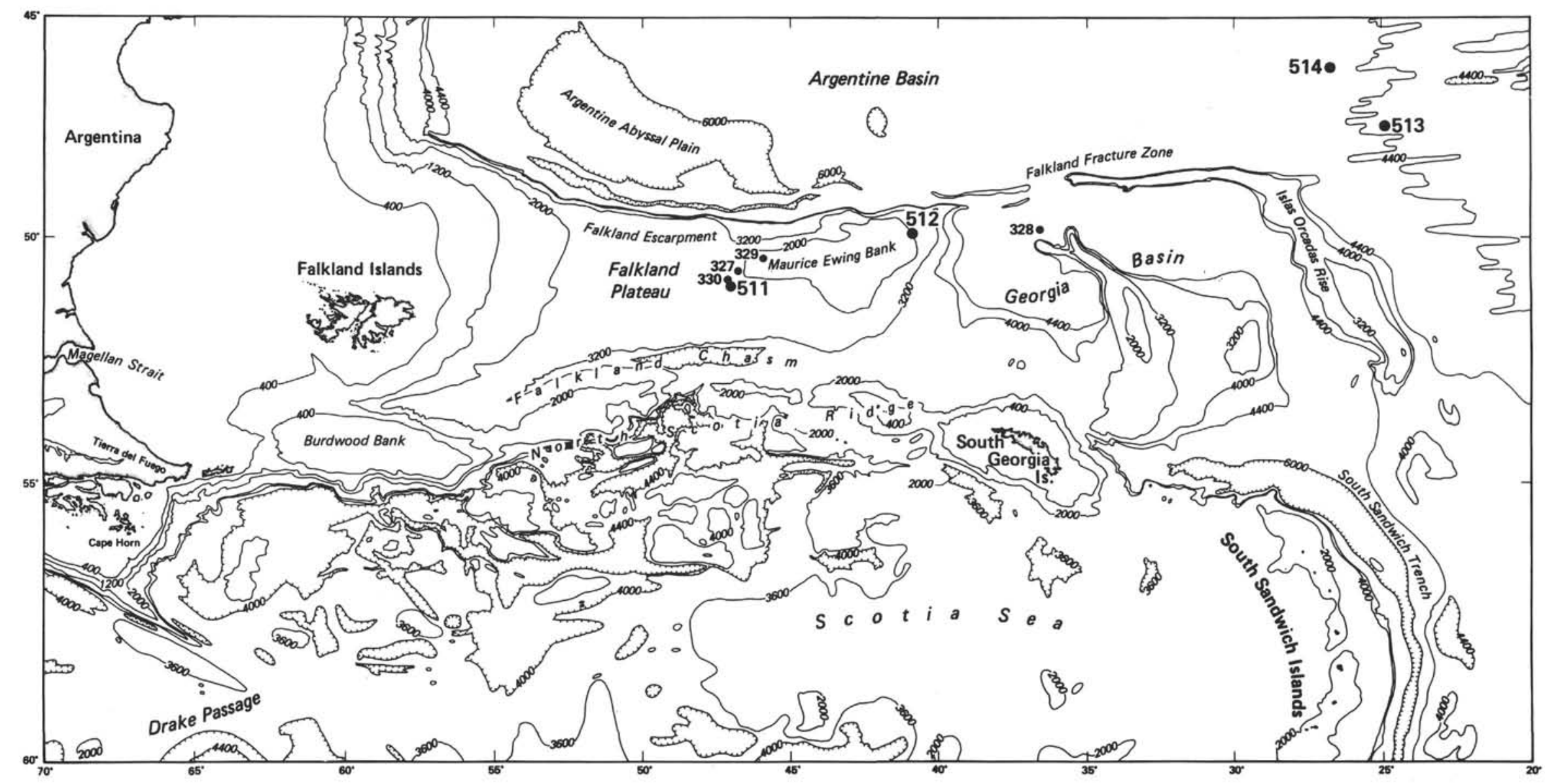

Figure 1. Location of DSDP Sites 511, 512, 513, and 514. 
A Leitz Dialux 20 light microscope was used to determine the relative abundance of diatoms. Relative abundances are based on an examination of the entire whole fraction slide (at $500 \times$ ) and are designated as follows: A, abundant, at least one specimen in every field of view; $\mathrm{C}$, common, at least one specimen in every two to five fields of view; F, frequent, at least one specimen in every six to ten fields of view; S, sparse, several specimens observed on the entire slide; $R$, rare, only one or two specimens observed on the entire slide. Sieved samples of selected intervals were examined for rare species; those taxa present only in sieved sample preparations were always rare. Lower case letters for abundance symbols are used for occurrences that are believed to represent reworked specimens.

\section{ZONATION}

The Neogene and Quaternary diatom zonation presented here represents the upper middle Miocene to Holocene; older Miocene sediments were missing from Leg 71 sites (Fig. 2). Defined are 15 diatom zones (Figs. 3 and 4): 5 zones are unchanged from McCollum (1975) and Weaver and Gombos (1981), 5 zones of these authors are revised, and 5 new zones are described. The Pliocene-Holocene zonation described herein is compared with the previous zonations of McCollum (1975) and Weaver and Gombos (1981) in Figure 5. Upper middle Miocene to upper Miocene diatom, radiolarian, and silicoflagellate zonations are correlated to magnetostratigraphy in Figure 6.

The Pliocene-Holocene zonal scheme presented here includes thirteen zones and the upper portion of a fourteenth, the Denticulopsis hustedtii Zone. The absolute ages of the boundaries of these zones, except the bases of the Coscinodiscus lentiginosus, Nitzschia angulata, and $N$. reinholdii zones, are based on the magnetostratigraphic record of Hole 514. To estimate the ages of the zonal boundaries, the sub-bottom depths were first determined for all paleomagnetic polarity boundaries and zonal boundaries. Most paleomagnetic polarity boundaries were determined to within a $2-20 \mathrm{~cm}$ interval by Salloway and Bloemendal (both this volume). The subbottom depths of diatom zonal boundaries were calculated as the midpoint between studied samples bracketing the zonal boundaries. Zonal boundary ages were then calculated by assuming constant sediment accumulation rates between adjacent chronozone or subchronozone boundaries and the sub-bottom depth estimated for the zonal boundaries.

The absolute age estimates of the diatom zones based on Hole 514 are more accurate than previous estimates based on studies of piston cores because of high sediment accumulation rates (up to $145 \mathrm{~m} / \mathrm{m}$.y.). I am now studying additional samples from the vicinity of zonal boundaries in order to define them more accurately by more precisely determining the sub-bottom depths of zonal boundaries. As presently defined, Pliocene-Holocene diatom zones have a duration ranging from a maximum of $980,000 \mathrm{yr}$. to a minimum of $140,000 \mathrm{yr}$., with an average of $373,000 \mathrm{yr}$.

No attempt is made here to establish a more detailed zonation of the upper Miocene to lower Pliocene (Chronozone 10 to lower Gilbert Chronozone). Several additional biostratigraphic datums were identified in this interval but were not used for further subdivision because there is no information on their regional significance.
The following description of the diatom zonation does not discuss intrazonal biostratigraphic datums or assemblage characteristics. These data may be obtained by reference to McCollum (1975), Gombos (1977), Weaver and Gombos (1981), and the appropriate tables and figures in this chapter.

\section{Coscinodiscus lentiginosus Partial Range Zone}

Author. McCollum, 1975.

Top. Holocene.

Bottom. Last occurrence of Actinocyclus ingens.

Age. Pleistocene.

Paleomagnetic correlation. McCollum (1975) placed the base of this zone coincident with the Brunhes/Matuyama Chronozone boundary. Weaver and Gombos (1981) place the same boundary in the lower Brunhes Chronozone ( $\sim 0.6$ to $0.5 \mathrm{Ma}$ ) but cite no reason for doing so. In all cores that I have examined from antarctic and subantarctic areas of the Southeast Indian and Atlantic sectors of the Southern Ocean, the base of the zone consistently occurs in the lower Brunhes Chronozone (Ciesielski et al., 1982; Ledbetter and Ciesielski, 1982; Osborn et al., in press). My best estimate for the age of the zone base comes from Islas Orcadas (IO) piston core $11-70$ from the Southeast Atlantic $\left(55^{\circ} 09.0^{\prime} \mathrm{S}\right.$, $\left.09^{\circ} 58.9^{\prime} \mathrm{E}, 4521 \mathrm{~m}\right)$. Assuming a constant sediment accumulation rate for the Brunhes section of this core, the base of the zone between 1048 and $1068 \mathrm{~cm}$ is $\sim 620,000$ y.B.P.

Absolute age. 620,000 y.B.P.-Present.

\section{Coscinodiscus elliptopora/Actinocyclus ingens Partial Range Zone}

Authors. Bottom, Ciesielski, this chapter; top, McCollum, 1975.

Top. Last occurrence of Actinocyclus ingens.

Bottom. Last occurrence of Rhizosolenia barboi.

Remarks. McCollum (1975) defined the base of the zone as the first occurrence of Coscinodiscus elliptopora. This boundary is emended here for two major reasons. First, McCollum's definition of the base of this zone differs from his definition of the top of the underlying Rhizosolenia barboi/Nitzschia kerguelensis Zone, which he defined by the last occurrence of $R$. barboi. Thus the boundary between the $C$. lentiginosus and $R$. barboi/N. kerguelensis zones may vary, because the first occurrence of $C$. elliptopora occurs prior to the last occurrence of $R$. barboi (Ciesielski, 1978; Ciesielski et al., 1982, fig. 10; Ciesielski, this chapter, Table 3). Second, the first occurrence of $C$. elliptopora has been observed to occur over a wide range of stratigraphic levels within the Matuyama Chronozone (Ciesielski, 1978; unpublished data from Ledbetter and Ciesielski, 1982; Osborn et al., in press). Diachrony in the first occurrence of $C$. elliptopora is caused by its sometimes sporadic occurrence, even in well-preserved sediments, and its scarcity or absence in poorly preserved sediments.

The base of the $C$. elliptopora/Actinocyclus ingens Zone is changed, therefore, to the last occurrence of $R$. barboi; thus it is now defined as being the same as the top of the underlying $R$. barboi/N. kerguelensis Zone. 

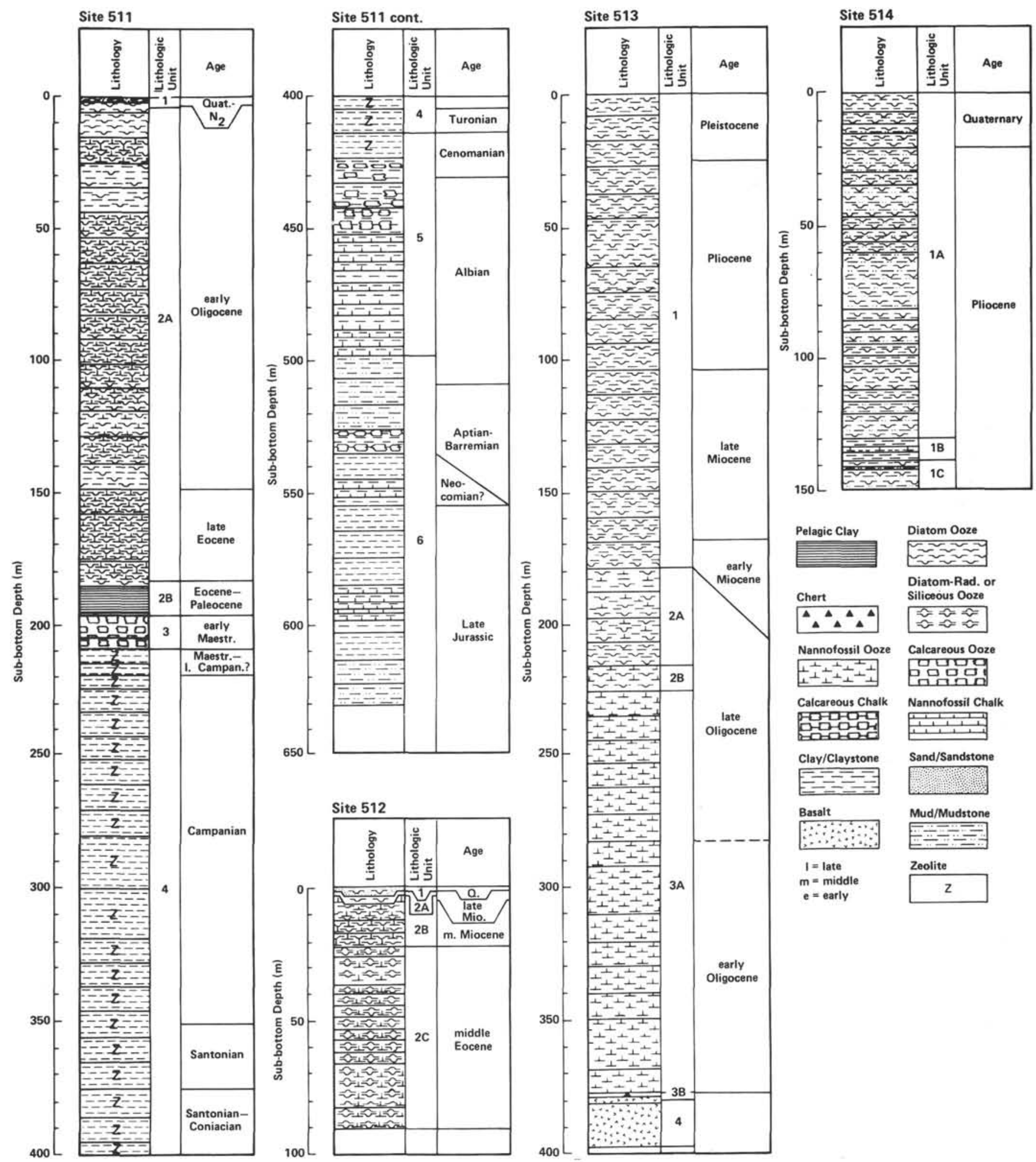

Figure 2. Lithologic columnar sections of DSDP Sites 511, 512, 513, and 514.

Age. Pleistocene.

Paleomagnetic correlation. In Hole 514 the last occurrence of Rhizosolenia barboi occurs between Samples 514-5-4, 56-58 cm and 514-6-1, 77-79 $\mathrm{cm}$ at, an estimated sub-bottom depth of 18.91 meters and age of
1.58 Ma. A similar age, $1.53 \mathrm{Ma}$, is estimated for the boundary in piston core IO 16-107. In these and other sections the last $R$. barboi occurs above the top of the Olduvai Subchronozone of the Matuyama Chronozone. 


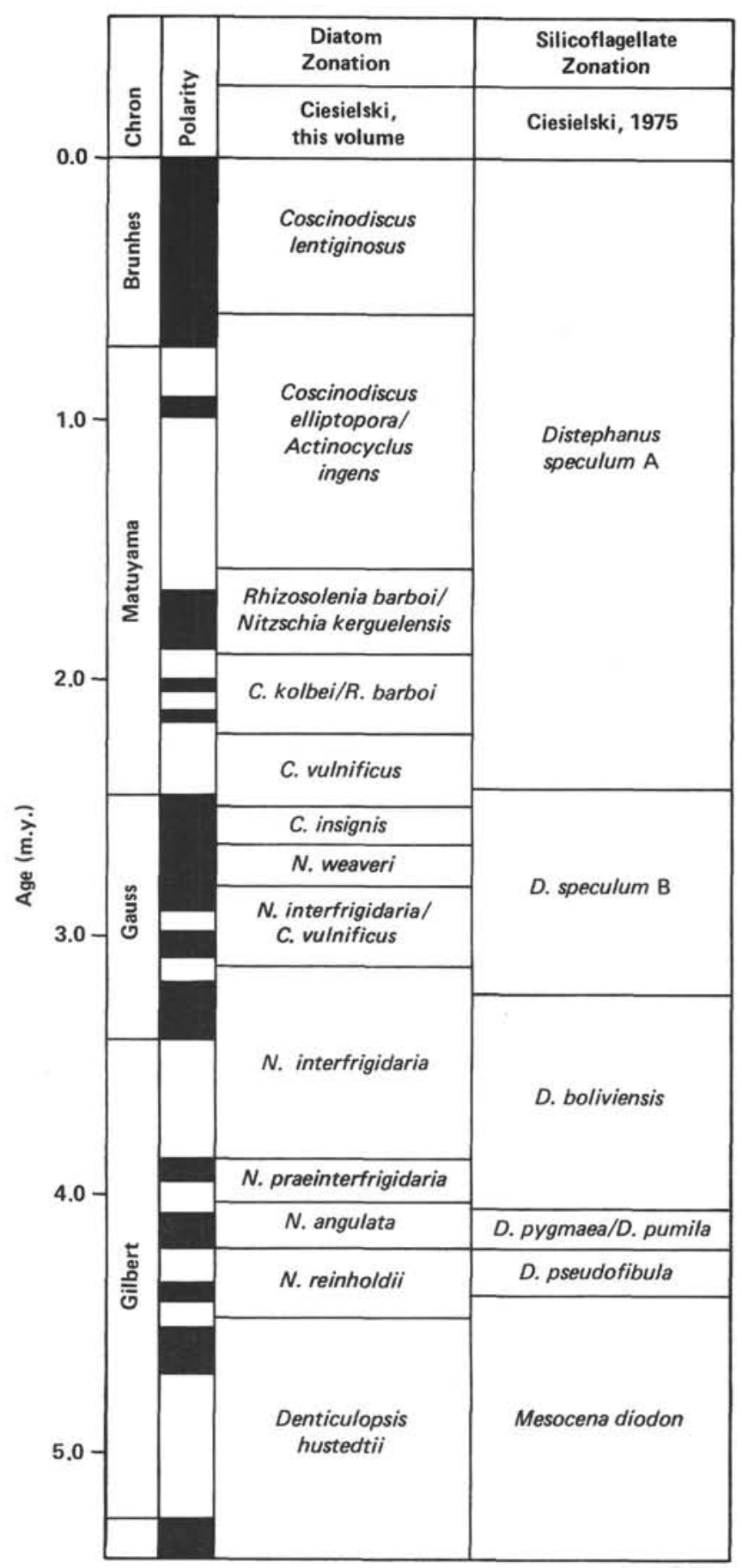

Figure 3. Pliocene to Quaternary diatom and silicoflagellate zonation correlated to paleomagnetic stratigraphy.

\section{Rhizosolenia barboi/Nitzschia kerguelensis Partial Range Zone}

Authors. Bottom, McCollum, 1975, emended here; top, McCollum, 1975.

Top. Last occurrence of Rhizosolenia barboi.

Bottom. Last occurrence of Coscinodiscus kolbei.

Distinguishing characteristic. Joint occurrence of Rhizosolenia barboi and Nitzschia kerguelensis, following the latest occurrence of Coscinodiscus kolbei.

Remarks. McCollum (1975) defined the base of the zone by the joint occurrence of Rhizosolenia barboi and

\begin{tabular}{|c|c|}
\hline Zone Names & \multirow[t]{2}{*}{ Zonal Definitions } \\
\hline $\begin{array}{c}\text { Coscinodiscus lentiginosus } \\
\text { PRZ }\end{array}$ & \\
\hline $\begin{array}{c}\text { C. elliptopora/A. ingens } \\
\text { PRZ }\end{array}$ & $\begin{array}{l}\text { Last occurrence of } \\
\text { Actinocyclus ingens }\end{array}$ \\
\hline R. barboi/N. kerguelensis & $\begin{array}{l}\text { Last occurrence of } \\
\text { Rhizosolenia barboi }\end{array}$ \\
\hline & \multirow{2}{*}{$\begin{array}{c}\text { Last occurrence of } \\
\text { C. kolbei }\end{array}$} \\
\hline C. kolbei/R. barboi & \\
\hline PRZ & \multirow{2}{*}{$\begin{array}{l}\text { Last occurrence of } \\
\text { C. vulnificus }\end{array}$} \\
\hline C. vulnificus & \\
\hline Cosmiodiscus insignis & $\begin{array}{l}\text { Last occurrence of } \\
\text { Cosmiodiscus insignis }\end{array}$ \\
\hline PRZ & \multirow{2}{*}{$\begin{array}{l}\text { Last occurrence of } \\
\text { N. weaveri }\end{array}$} \\
\hline Nitzschia weaveri & \\
\hline & \multirow{2}{*}{$\begin{array}{l}\text { Last occurrence of } \\
N . \text { interfrigidaria }\end{array}$} \\
\hline $\begin{array}{c}N . \text { interfrigidaria/C. vulnificus } \\
\text { CRZ }\end{array}$ & \\
\hline & $\begin{array}{c}\text { First concurrent occurence of } \\
\text { C. insignis and } \\
\text { Coscinodiscus vulnificus }\end{array}$ \\
\hline PRZ & \multirow{2}{*}{$\begin{array}{c}\text { First occurrence of } \\
\text { N. weaveri }\end{array}$} \\
\hline N. praeinterfrigidaria & \\
\hline PRZ & \multirow{2}{*}{$\begin{array}{l}\text { First occurrence of } \\
N . \text { interfrigidaria }\end{array}$} \\
\hline N. angulata & \\
\hline PRZ & \multirow{2}{*}{$\begin{array}{l}\text { First occurrence of } \\
N \text {. angulata }\end{array}$} \\
\hline N. reinholdii & \\
\hline$\frac{12}{0.0}$ & $\begin{array}{l}\text { Last consistent occurrence of } \\
\text { Denticulopsis hustedtii }\end{array}$ \\
\hline $\begin{array}{c}\text { Denticulopsis hustedtii } \\
\text { PRZ }\end{array}$ & $\begin{array}{c}\text { Last occurrence of } \\
D . \text { lauta }\end{array}$ \\
\hline
\end{tabular}

Figure 4. Names and definitions of the new Pliocene-Quaternary zonation presented here. (PRZ, Partial Range Zone; CRZ, Concurrent Range Zone; IZ, Interval Zone.)

Nitzschia kerguelensis following the latest occurrence of Coscinodiscus kolbei. This definition is unsatisfactory because it defines the zone itself, not the base. For the purpose of clarity the base is redefined here as solely the last occurrence of $C$. kolbei.

Age. earliest Pleistocene.

Paleomagnetic correlation. In Hole 514 the base of the zone (last Coscinodiscus kolbei) occurs between Samples 514-6-3, 77-79 cm and 514-6-2, 80-82 cm at an estimated sub-bottom depth of 21.85 meters and age of $1.89 \mathrm{Ma}$. The base of the Olduvai Subchronozone (1.88 Ma) occurs between 118 and $136 \mathrm{~cm}$ of Section 514-62 , which places the paleomagnetic boundary within the samples bracketing the last occurrence of $C$. kolbei. Elsewhere in the Southern Ocean, the base of this zone has been found closely to approximate the base of the Olduvai Subchronozone (Ciesielski, 1978; unpublished data from Ledbetter and Ciesielski, 1982; Osborn et al., in press). On the basis of fewer piston cores, McCollum (1975) placed the base of the zone within the Olduvai Subchronozone (1.80-1.85 Ma).

Absolute age. 1.89-1.58 Ma.

\section{Coscinodiscus kolbei/Rhizosolenia barboi Partial Range Zone}

Authors. Bottom; Ciesielski, this paper; top, McCollum, 1975, emended here. 


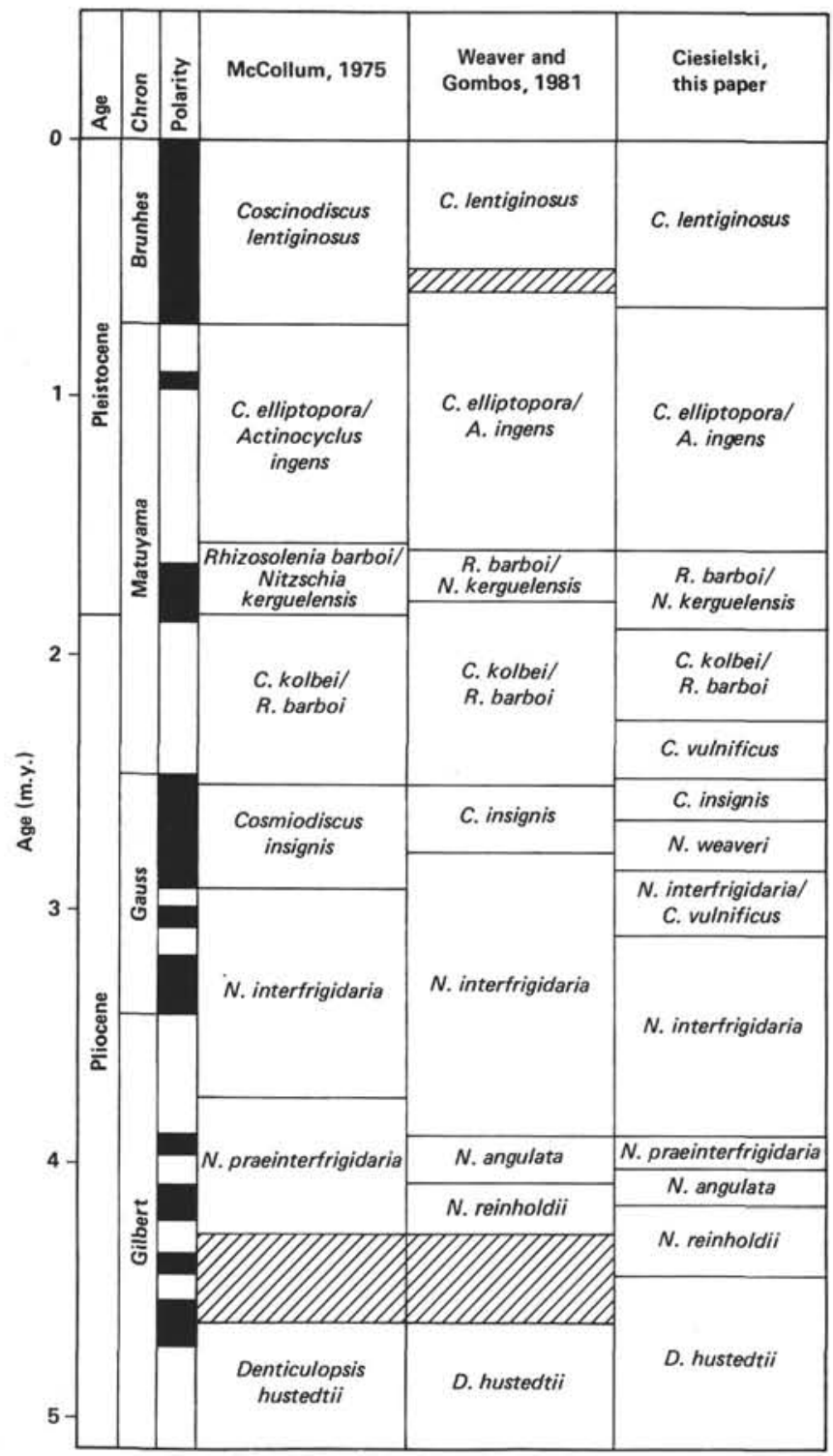

Figure 5. Comparison of the Pliocene-Quaternary diatom zonation Presented here with the previous zonations of McCollum (1975) and Weaver and Gombos (1981).

Top. Last occurrence of Coscinodiscus kolbei.

Bottom. Last occurrence of Coscinodiscus vulnificus.

Distinguishing characteristic. Joint occurrence of Coscinodiscus kolbei and Rhizosolenia barboi in the absence of $C$. vulnificus.

Remarks. McCollum (1975) defined the base of the zone by the latest occurrence of Cosmiodiscus insignis. Weaver and Gombos (1981) were the first to note the last occurrence of Coscinodiscus vulnificus as an important datum within the zone but elected to use it as an intrazonal datum rather as a zonal indicator. During the course of recent studies of over 400 piston cores from the Atlantic and Southeast Indian sectors of the Southern Ocean, I have consistently noted the last occurrence of C. vulnificus in the lower Matuyama Chronozone of antarctic and subantarctic piston cores (Ledbetter and Ciesielski, 1982; Osborn, et al., in press; Ciesielski and

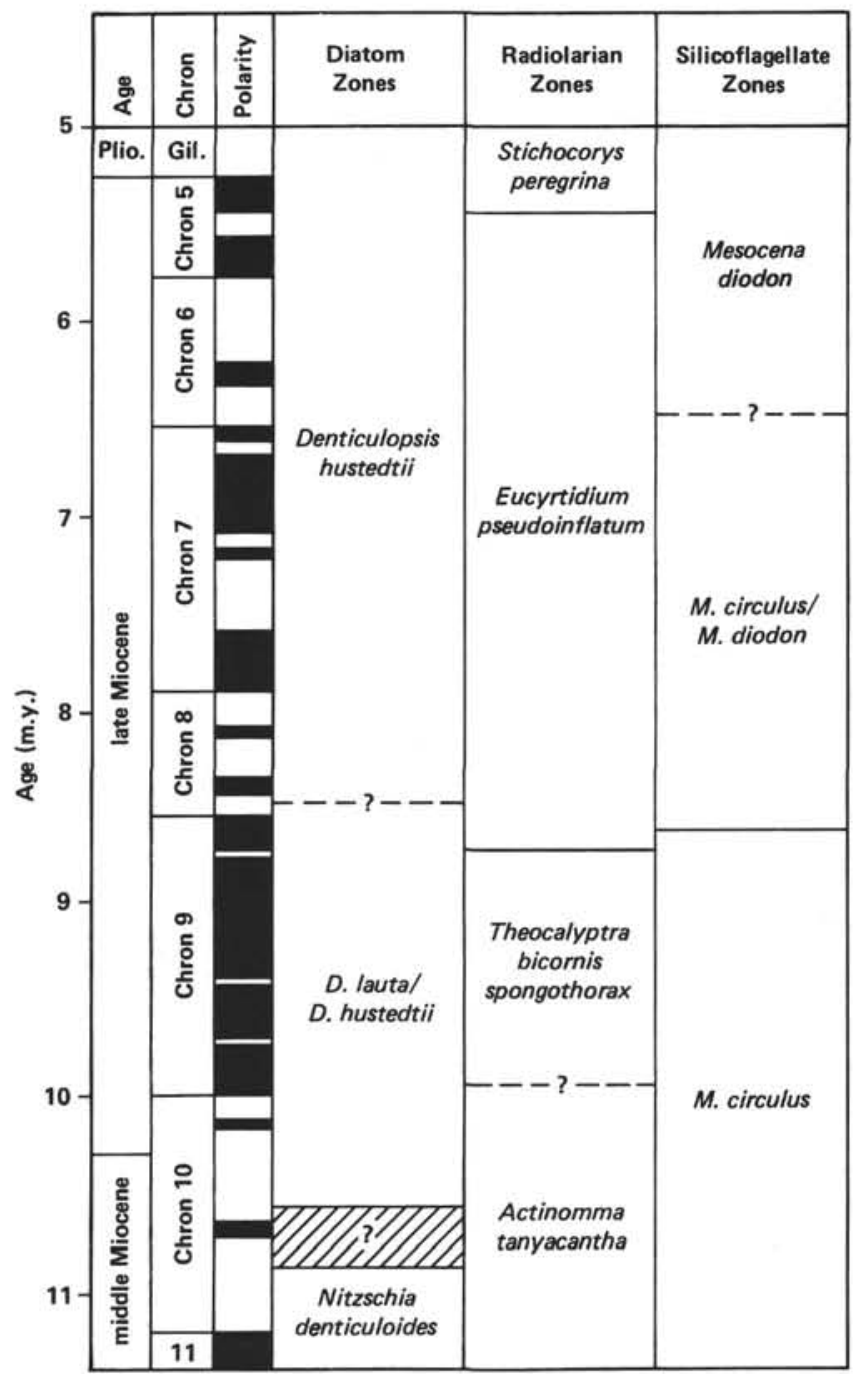

Figure 6. Upper middle Miocene to upper Miocene diatom, radiolarian, and silicoflagellate zones correlated to paleomagnetic stratigraphy.

Ledbetter, unpublished data). It therefore seems appropriate to use the last occurrence of $C$. vulnificus further to subdivide the lower Matuyama Chronozone.

Age. late Pliocene.

Paleomagnetic correlation. As defined by McCollum (1975), this zone included the entire Matuyama Chronozone below the Olduvai Subchronozone. The redefinition of the base of the zone here divides the portion of the Matuyama Chronozone below the Olduvai into two zones, the Coscinodiscus kolbei/Rhizosolenia barboi Zone and the $C$. vulnificus Zone.

In Hole 514 , the base of the zone occurs between Samples 514-9-3, 63-65 cm and 514-9-2, 70-72 $\mathrm{cm}$ at an estimated sub-bottom depth of 34.95 meters and age of 2.22 Ma. Although the Réunion subchronozones were not recognized in Hole 514, the calculated age of 2.22 $\mathrm{Ma}$ for the base of the zone would fall below these subchronozones. In piston core IO 16-107 from the nearby Islas Orcadas Rise, the last $C$. vulnificus falls between the two Réunion subchronozones (2.04-2.12 Ma). There thus appears to be a $100,000-y r$. difference in the age of 
the base of the zone as estimated from Hole 514 and from IO 16-107. A more definitive placement of the boundary with respect to the Réunion subchronozones awaits more detailed study of these and other sections.

Absolute age. $2.22-1.89 \mathrm{Ma}$.

\section{Coscinodiscus vulnificus Partial Range Zone}

Author. Ciesielski, this chapter.

Top. Last occurrence of Coscinodiscus vulnificus.

Bottom. Last occurrence of Cosmiodiscus insignis.

Age. late Pliocene.

Paleomagnetic correlation. The base of the zone in Hole 514 occurs between Samples 514-12-2, 26-28 cm and $514-12-1,50-52 \mathrm{~cm}$ at an estimated sub-bottom depth of 46.29 meters, 1.58 meters below the Gauss/ Matuyama Chronozone boundary. The estimated age of the basal boundary is $2.49 \mathrm{Ma}$, only $20,000 \mathrm{yr}$. older than the $2.47 \mathrm{Ma}$ Gauss/Matuyama boundary. In piston cores examined, all with a sediment accumulation rate an order of magnitude less than the $98 \mathrm{~m} / \mathrm{m}$.y. rate for the age-equivalent section of Hole 514, the basal boundary of the zone also falls in the uppermost Gauss near the Gauss/Matuyama boundary. This age for the last occurrence of Cosmiodiscus insignis is in excellent agreement with the $2.5 \mathrm{Ma}$ age assigned by McCollum from his studies of only a few piston cores.

Reference section. Sample 514-12-1, 50-52 cm through 514-9-3, 63-65 cm.

Absolute age. 2.49-2.22 Ma.

\section{Cosmiodiscus insignis Partial Range Zone}

Authors. Bottom, Ciesielski, this chapter; top, McCollum, 1975.

Top. Last occurrence of Cosmiodiscus insignis.

Bottom. Last occurrence of Nitzschia weaveri.

Remarks. McCollum defined the base of the zone by the last occurrence of Nitzschia interfrigidaria. The last occurrence of the new species $N$. weaveri is used here to redefine the base of the zone, thus increasing biostratigraphic resolution of the upper Gauss Chronozone.

Age. late Pliocene.

Paleomagnetic correlation. As defined by McCollum (1975) this zone encompassed most of the upper normalpolarity interval of the Gauss Chronozone, extending from just below the Gauss/Matuyama boundary $(\sim 2.5$ $\mathrm{Ma})$ to the Kaena Subchronozone (2.92 Ma). In Hole 514 the base of the zone occurs between Samples 514$15-3,70-72 \mathrm{~cm}$ and $514-15-2,70-72 \mathrm{~cm}$ at an estimated sub-bottom depth of 61.35 meters and age of $2.64 \mathrm{Ma}$. The Cosmiodiscus insignis Zone thus represents the upper portion of the upper normal-polarity portion of the Gauss Chronozone.

Absolute age. 2.64-2.49 Ma.

\section{Nitzschia weaveri Partial Range Zone}

Author. Ciesielski, this chapter.

Top. Last occurrence of Nitzschia weaveri.

Bottom. Last occurrence of Nitzschia interfrigidaria.

Remarks. This zone and the newly defined Cosmiodiscus insignis Zone are correlative to the $C$. insignis Zone of McCollum (1975). The last occurrence of $N$. weaveri is used here to subdivide McCollum's (1975) $C$. insignis Zone into the $N$. weaveri Zone and newly defined $C$. insignis Zone.

Age. late Pliocene.

Paleomagnetic correlation. This zone represents the basal portion of the upper normal-polarity interval of the Gauss Chronozone. In Hole 514 the base of the zone occurs between Samples 514-19-2, 72-74 cm and 514$19-1,72-74 \mathrm{~cm}$ at an estimated depth of 77.48 meters and age of $2.81 \mathrm{Ma}$.

Reference section. Samples $514-15-3,70-72 \mathrm{~cm}$ through 514-19-1, 72-74 cm.

Absolute age. 2.81-2.64 Ma.

\section{Nitzschia interfrigidaria/Coscinodiscus vulnificus Concurrent Range Zone}

Author. Ciesielski, this chapter.

Top. Last occurrence of Nitzschia interfrigidaria.

Bottom. First concurrent occurrence of Cosmiodiscus insignis and Coscinodiscus vulnificus.

Remarks. One of the shortcomings of the diatom zonations of McCollum (1975) and Weaver and Gombos (1981) is that the upper Gilbert to lower Gauss Chronozones are embraced by a single diatom zone, the Nitzschia interfrigidaria Zone. This interval records major changes in Southern Ocean paleoceanography (Ciesielski et al., 1982; Ciesielski and Weaver, this volume) and needs further subdivision. Here the $N$. interfrigidaria/Coscinodiscus vulnificus Zone and emended $N$. interfrigidaria Zone are closely representative of the $N$. interfrigidaria Zone as previously defined.

Age. late Pliocene.

Paleomagnetic correlation. In Hole 514 the base of the zone occurs between Samples 514-26-1, 98-100 cm and 514-25-1, 95-97 $\mathrm{cm}$ at an estimated sub-bottom depth of 105.58 meters and age of $3.1 \mathrm{Ma}$. The zone includes the lower portion of the upper normal-polarity portion of the Gauss Chronozone, the Kaena Subchronozone, and middle normal-polarity interval of the Gauss, and has its lower boundary within the midMammoth Subchronozone.

Reference section. Samples 514-19-2, 72-74 cm through 514-25-1, 95-97 cm.

Absolute age. 3.10-2.81 Ma.

\section{Nitzschia interfrigidaria Partial Range Zone}

Author. Ciesielski, this chapter.

Top. First concurrent occurrence of Cosmiodiscus insignis and Coscinodiscus vulnificus.

Bottom. First occurrence of Nitzschia weaveri.

Remarks. The Nitzschia interfrigidaria Zone as defined here is partially equivalent to the $N$. interfrigidaria Zone of McCollum (1975) and Weaver and Gombos (1981). The complete zone is not present in any of the Leg 71 sites, and in Hole 514 only the upper and lowermost portions of the zone are present. Disconformities are present in most Southern Ocean piston cores containing the $N$. interfrigidaria Zone (Ciesielski, 1978; Ciesielski et al., 1982; Ledbetter and Ciesielski, 1982; and others). Further subdivision of this interval is needed but awaits examination of more complete sections. 
Age. early-late Pliocene.

Paleomagnetic correlation. In Hole 514 the base of the zone occurs between Samples 514-28-1, 90-92 cm and $514-27-2,84-86 \mathrm{~cm}$ at an estimated sub-bottom depth of 115.03 meters and age of $3.88 \mathrm{Ma}$. The Nitzschia interfrigidaria Zone extends from within the Mammoth Subchronozone to the uppermost Cochiti Subchronozone of the Gilbert Chronozone.

Reference section. None designated.

Absolute age. 3.88-3.1 Ma.

\section{Nitzschia praeinterfrigidaria Partial Range Zone}

Author. Ciesielski, this chapter.

Top. First occurrence of Nitzschia weaveri.

Bottom. First occurrence of Nitzschia interfrigidaria.

Remarks. McCollum (1975) established the Nitzschia praeinterfrigidaria Zone to include the interval from the last Denticulopsis hustedtii to the last $N$. interfrigidaria. As he defined the zone it includes the Gilbert Chronozone from the Cochiti to Sidufjall-Thvera subchronozones. Weaver and Gombos (1981) substituted the $N$. reinholdii and $N$. angulata zones for McCollum's (1975) $N$. praeinterfrigidaria Zone and suggested their use in regions north of $62^{\circ} \mathrm{S}$ latitude; south of this latitude they suggested use of McCollum's $N$. praeinterfrigidaria Zone. The $N$. angulata and $N$. reinholdii zones are utilized here, but the $N$. angulata Zone of Weaver and Gombos (1981) is emended and a third zone created to subdivide McCollum's (1975) N. praeinterfrigidaria Zone further. I here conserve the name $N$, praeinterfrigidaria Zone to refer to that portion of McCollum's original $N$. praeinterfrigidaria Zone between the first occurrence of $N$. interfrigidaria and first occurrence of $N$. weaveri.

Age. early Pliocene.

Paleomagnetic correlation. In Hole 514 the base of the zone occurs between Samples 514-33-1, 75-77 cm and 514-32-1, 77-79 $\mathrm{cm}$ at an estimated depth of 136.17 meters and age of $4.02 \mathrm{Ma}$. The zonal base occurs below the base of the Cochiti Subchronozone and above the Nunivak Subchronozone.

The base of the newly defined Nitzschia praeinterfrigidaria Zone, the first occurrence of $N$. interfrigidaria, is $\sim 120,000 \mathrm{yr}$. older than the base of the $N$. interfrigidaria Zone of Weaver and Gombos (1981), as recognized by the change in dominance from $N$. praeinterfrigidaria to $N$. interfrigidaria. This change now occurs within the newly defined $N$. praeinterfrigidaria Zone, thus eliminating the necessity of making quantitative or qualitative estimates of changes from the dominance of $N$. praeinterfrigidaria to that of $N$. interfrigidaria.

Reference section. None designated at this time.

Occurrence. The zone appears to be applicable in all antarctic and subantarctic latitudes.

Absolute age. 4.02-3.88 Ma. The zone represents only $\sim 140,000 \mathrm{yr}$. but is easily recognized in piston cores because of high sediment accumulation rates at this time throughout the Southern Ocean.

\section{Nitzschia angulata Partial Range Zone}

Authors. Bottom, Weaver and Gombos, 1981; top, Ciesielski, this chapter.

Top. First occurrence of Nitzschia interfrigidaria.
Bottom. First occurrence of Nitzschia angulata.

Remarks. Weaver and Gombos (1981) defined the top of the zone by the evolutionary transition from Nitzschia praeinterfrigidaria to $N$. interfrigidaria, which they recognize by the change in dominance from $N$. praeinterfrigidaria to $N$. interfrigidaria. This definition was utilized because McCollum's (1975) incomplete diagnosis of $N$. praeinterfrigidaria and $N$. interfrigidaria prevented recognition of the first occurrence of $N$. interfrigidaria or last occurrence of $N$. praeinterfrigidaria (Weaver and Gombos, 1981; pers. comm. from F. M. Weaver, 1981). A full diagnosis of these species is given here (see taxonomy). Thus recognition of the first $N$. interfrigidaria is straightforward and is used to define the top of the zone.

Paleomagnetic correlation. Hole 514 was terminated before the base of the Nitzschia angulata Zone was encountered. Weaver and Gombos (1981) correlate the base of the zone with the top of the Nunivak Subchronozone of the Gilbert Chronozone. During the course of my examination of numerous Southern Ocean piston cores, I have noted that the basal boundary of the zone is diachronous. In some cores this boundary occurs in the upper portion of the Nunivak Subchronozone; however, in most cores the basal boundary occurs near the base of this Subchronozone. Until a more thorough study can be made of piston cores containing this zone, the basal boundary is placed in the lower Nunivak Subchronozone. The Nitzschia angulata Zone thus represents a portion of the reversed-polarity interval between the Cochiti and Nunivak/Subchronozones and most or all of the Nunivak Subchronozone.

Absolute age. 4.20-4.02 Ma. Even though this zone represents only $\sim 180,000 \mathrm{yr}$. It is readily recognized where present, because this interval is characterized by very high sedimentation rates throughout the Southern Ocean (e.g., Hole 514, 180 m/m.y.).

\section{Nizschia reinholdii Interval Zone}

Authors. Weaver and Gombos, 1981.

Top. First occurrence of Nitzschia angulata.

Bottom. Last abundance appearance datum of Denticulopsis hustedtii.

Age. early Pliocene.

Paleomagnetic correlation. Weaver and Gombos (1981) were unable accurately to determine the base of the, zone relative to paleomagnetic chronostratigraphy because their reference sections did not contain both the Sidufjall and Thvera subchronozones (informally known as the "cc" subchronozones). The authors, therefore, extended the zone to these subchronozones, undifferentiated.

Final clarification of the position of the zonal base must await further study of a significant number of cores with both "c" subchronozones. At this time I tentatively place the base of the Nitzschia reinholdii Zone between the Sidufjall and Thvera subchronozones, based on preliminary studies of piston cores IO 11-66 and IO 7-5.

Piston cores containing the lower Gilbert Chronozones and Chronozone 5 are rare. Further studies of existing cores containing this interval are under way and 
should clarify the position of the base of the Nitzschia reinholdii Zone.

Absolute age. 4.48-4.20 Ma.

\section{Denticulopsis hustedtii Partial Range Zone}

Authors. Bottom, McCollum, 1975; top, Weaver and Gombos, 1981.

Top. Last abundance appearance datum of Denticulopsis hustedtii.

Bottom. Last occurrence of Denticulopsis lauta.

Age. late Miocene-early Pliocene.

Paleomagnetic correlation. Extrapolating from average sedimentation rates at DSDP Site 278, Weaver (1976) estimated the base of the zone at $6.8-7.0 \mathrm{Ma}$ or within Chron 7. Ciesielski (1978) has shown the base of the zone to be at least as old as Chron 6. Ciesielski (1980) believed the basal boundary possibly fell in midChron 7 ( $7.1 \mathrm{Ma})$ based on piston core IO 7-48.

During the course of Leg 71 micropaleontologic investigations, Ciesielski and Weaver re-examined piston cores IO 7-48 and IO 7-54 in an attempt to correlate the base of this and other upper Miocene diatom and radiolarian zones to magnetostratigraphy. Both piston cores have long normal-polarity sequences at their base (Ciesielski et al., 1982), which we correlate to upper Chronozone 9. Both Denticulopsis hustedtii and D. lauta are present throughout the interval we identify as Chronozone 9.

A portion of core IO 7-48 disconformably above Chronozone 9 was identified as mid-Chronozone 7 by Ciesielski (1980) and was thought to contain the lower boundary of the $D$. hustedtii Zone. Our subsequent reexamination of this core shows this boundary to be unreliable because of considerable reworking and a possible disconformity. Thus, based on piston core studies, the base of the Denticulopsis hustedtii Zone can be no more definitively placed than between upper Chronozone 9 and lower Chronozone 6.

A volcanic ash in Hole 513A radiometrically dated by R. D. Dallmeyer (University of Georgia; pers. comm., 1981) provides additional insight into the age of the last occurrence datum of Denticulopsis lauta. The ${ }^{40} \mathrm{Ar} /{ }^{36} \mathrm{Ar}$ versus ${ }^{39} \mathrm{Ar} /{ }^{36} \mathrm{Ar}$ isochron age for the incremental gas analysis of the ash from Sample 513A-10-1, 13-15 cm was $8.7 \mathrm{~m} . \mathrm{y} . \pm 0.2 \mathrm{~m} . \mathrm{y}$. Rare to sparse $D$. lauta occur above this ash up to the disconformity between Core 10 and Core 9; therefore, the last occurrence of the species is younger than $8.7 \pm 0.2 \mathrm{Ma}$. Specimens above the ash layer are small and poorly silicified. These characteristics and the low abundance of $D$. lauta are usually indicative of the uppermost portion of its range. It seems likely, therefore, that the last occurrence of $D$. lauta is in lower Chronozone 8. The last abundance appearance datum of $D$. lauta is probably only slightly older than the volcanic ash, because the species is common in the sample immediately below the ash. Until a more complete section can be studied, the date of the ash layer will be used to approximate the last abundance appearance datum of $D$. lauta. The base of the D. hustedtii Zone, the last occurrence of $D$. lauta, is tentatively placed at approximately the Chronozone 9-Chronozone 8 boundary $(\sim 8.7-8.5 \mathrm{Ma})$.

The presence of D. lauta above the volcanic ash clearly indicates that the last occurrence of this species is younger in the subantarctic than in Japan, where Koizumi (1977) placed the datum at $9.5 \mathrm{Ma}$ on the basis of a $\mathrm{K}-\mathrm{Ar}$ date. A later disappearance of $D$. lauta in the subantarctic does not seem surprising given the cool-water affinity of the genus Denticulopsis.

Absolute age. Uncertain, 8.7 to 8.5-4.48 Ma.

\section{Denticulopsis hustedtii/Denticulopsis lauta Concurrent Range Zone}

Authors. Bottom, Weaver and Gombos, 1981; top, McCollum, 1975.

Top. Last occurrence of Denticulopsis lauta.

Bottom. Last abundant appearance datum of Nitzschia denticuloides.

Age. middle Miocene to early late Miocene. The last abundant appearance datum of Nitzschia denticuloides occurs abruptly in Hole 512, Core 2. This datum, the base of the zone, occurs just below the first Neogloboquadrina acostaensis and above the last Globorotalia siakensis; thus it is within the upper N15 planktonic foraminiferal zone and correlative to the basal Tortonian of the upper Miocene (Fig. 7).

Paleomagnetic correlation. The brevity of the Hole 512 upper middle to lower upper Miocene section prevents definitive correlation of the base of the zone to paleomagnetic stratigraphy. Interpretation of the paleomagnetic record is made more difficult by uncertain identification of the paleomagnetic polarity record of the type Tortonian section.

Two interpretations are presented here for the Miocene paleomagnetic polarity record of Hole 512 (Fig. 7). This section most likely represents either upper Chronozone 11 and lower through middle Chronozone 10 or most of Chronozone 11 and lower Chronozone 10. The Neogloboquadrina acostaensis datum first appears to be the key to interpreting the Hole 512 magnetostratigraphy. Opdyke et al. (1974) indirectly correlated this datum to upper Chronozone 11, whereas Ryan et al. (1974) placed the datum in the Tortonian stratotype within middle Chronozone 10 by correlating the stratotype magnetostratigraphy to a composite equatorial $\mathrm{Pa}$ cific magnetostratigraphy. In both interpretations of the Hole 512 magnetostratigraphy presented here, the $N$. acostaensis datum occurs within Chronozone 10, thus appearing to favor Ryan et al.'s (1974) placement and suggesting a similar occurrence in Hole 512. The base of the Denticulopsis hustedtii/D. lauta Zone would thus be mid-Chronozone 10 in age.

Unfortunately, neither interpretation of the Hole 512 magnetostratigraphy fits with the upper Chronozone 12 age for the N14/N15 planktonic foraminiferal boundary, which in Hole 512 occurs either in lower Chronozone 10 or mid Chronozone 11. Diachrony of this or other foraminiferal boundaries here may be the result of water mass migrations at this high-latitude site. Therefore, neither interpretation of the Hole 512 magneto- 


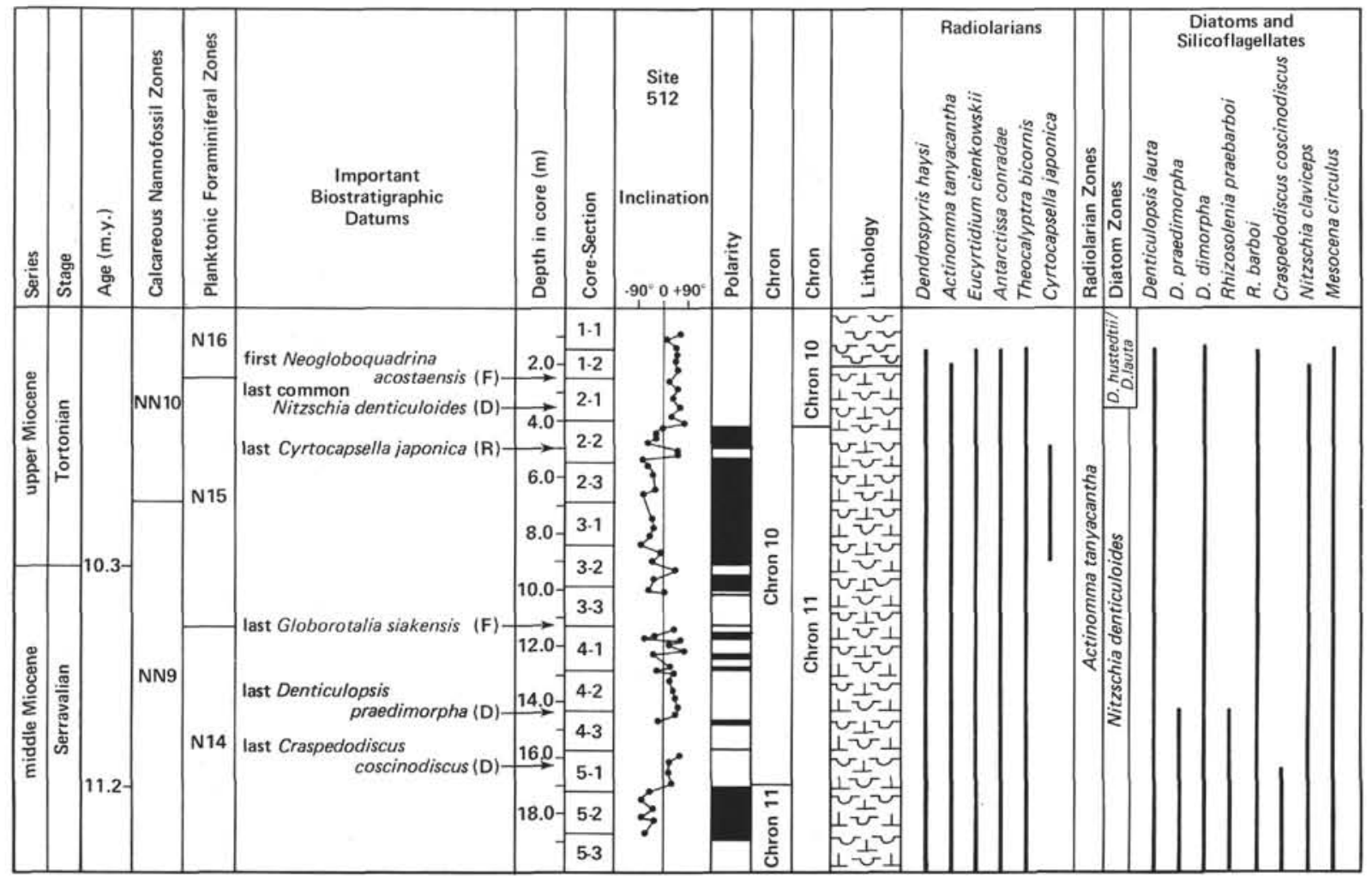

Figure 7. Ranges of selected diatoms, radiolarians, and silicoflagellates in the upper middle Miocene to upper Miocene of HPC Site 512. Magnetic polarity record by Ledbetter (this volume).

stratigraphy is followed at this time. A more definitive placement of the base of the Denticulopsis hustedtii/D. lauta Zone requires a more complete biostratigraphic record. For the present the base of the zone is designated as lower to middle Chronozone 10.

Absolute age. $\sim 11.2-10.5$ to $8.7-8.5 \mathrm{Ma}$.

\section{Nitzschia denticuloides Partial Range Zone}

Authors. Weaver and Gombos, 1981.

Top. Last abundance appearance datum of Nitzschia denticuloides.

Bottom. Last occurrence of Nitzschia grossepunctata.

Age. middle Miocene-earliest late Miocene. Weaver and Gombos (1981) estimate a 14.0 to $14.5 \mathrm{Ma}$ age for the base of the zone, based on extrapolation of sedimentation rates in DSDP Site 278. This estimate is consistent with the occurrence of the base of the zone in Site 2785 meters below the last occurrence of the nannofossil Cyclicargolithus floridanus, a datum which occurs within NN6 and is older than the $13.8 \mathrm{Ma}$ age of the top of NN6 (Weaver and Gombos, 1981).

Absolute age. $\sim 14.0-14.5 \mathrm{Ma}$ to $11.2-10.5 \mathrm{Ma}$.

\section{SITE SUMMARIES}

\section{Site 511 (Table 1)}

Site $511\left(51^{\circ} 00.28^{\prime} \mathrm{S}, 46^{\circ} 58.30^{\prime} \mathrm{W} ; 2589\right.$ meters $)$ is located in the basin province of the Falkland Plateau, about $10 \mathrm{~km}$ south of DSDP Site 330 on the Maurice Ewing Bank. The 70 cores drilled continuously at Site
511 range from Holocene to Neocomian age. This report examines only the diatoms of the Pliocene to Holocene sediments of Core 1. Diatoms from the upper Eocene-lower Oligocene sediments disconformably underlie Pliocene sediments of Core 1 and are described by Gombos and Ciesielski (this volume).

Diatoms are well preserved and abundant in Core 1. A detailed examination of this core revealed the presence of three disconformities. The siliceous gravelly sand and foraminiferal ooze from 0 to $37 \mathrm{~cm}$ of Section 1 is assigned to the Coscinodiscus lentiginosus Zone of the Brunhes Magnetic Chronozone.

The lithology change at $37 \mathrm{~cm}$ marks a disconformable boundary separating the upper $C$. lentiginosus Zone from the C. elliptopora/Actinocyclus ingens Zone encountered at 511-1-1, 52-53 cm. Sample 511-1-1, 91$92 \mathrm{~cm}$ is assigned to the C. kolbei/Rhizosolenia barboi Zone of the uppermost Pliocene.

No zonal designation is given to Sample 511-1-1, $120-121 \mathrm{~cm}$ because of considerable downhole slumping of younger microfossils and reworking of lower Pliocene and upper Miocene microfossils. This sample probably is close to an apparent disconformity separating lower Matuyama Chronozone sediments (511-1-1, 91$92 \mathrm{~cm}$ ) from upper Gauss Chronozone sediments (511-1$1,142-143 \mathrm{~cm}$ ) and may represent the Cosmiodiscus insignis Zone. Sample 511-1-1, 142-143 cm contains a flora characteristic of the Nitzschia weaveri Zone. Three samples from Core 1, Section 2 (at 31-31, 65-66, and $89-90 \mathrm{~cm}$ ) are assigned to the $N$. interfrigidaria/Coscinodiscus vulnificus Zone of the mid-Gauss and are ap- 
Table 1. Relative abundances of selected diatoms from the Pliocene to Quaternary of Hole 511, Core 1.

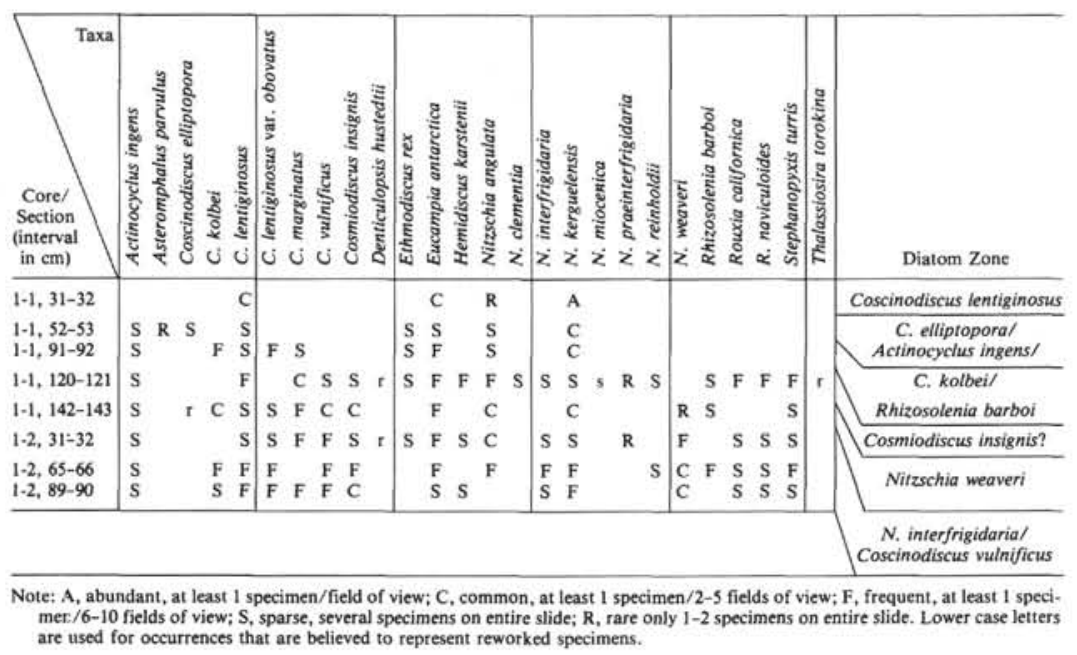

parently conformable to the $N$. weaveri Zone of basal Section 1.

The third disconformity in Core 1 probably is coincident with the sharp lithology change at $144 \mathrm{~cm}$ of Section 2 . This sharp boundary between the siliceous gravelly sand above and the diatom ooze below separates the middle Pliocene of Sample 511-1-2, 89-90 cm from the lower Oligocene of Sample 511-3-1, 4-5 cm.

\section{Site 512 (Table 2, Fig. 7)}

Site $512\left(49^{\circ} 52.19^{\prime} \mathrm{S}, 40^{\circ} 50.71^{\prime} \mathrm{W} ; 1846 \mathrm{~m}\right)$ lies on the northeastern part of the Maurice Ewing Bank at a location chosen to investigate further the depositional and erosional history of the Falkland Plateau. Hole 512 was continuously hydraulic piston cored to a sub-bottom depth of 77.9 meters where coring was suspended because sediments became too indurated to penetrate. A second hole, $512 \mathrm{~A}$, was rotary drilled after the hole was washed to the level where coring stopped in Hole 512. Only one core was recovered from Hole 512A, to a subbottom depth of 89.3 meters, before bad weather and sea conditions forced abandonment of the site.

Eleven samples examined from Hole 512, Core 1 are assigned to four diatom zones with a hiatus occurring between each zone. Samples 512-1-1, 13-14 cm, 512-1-1, $24-25 \mathrm{~cm}$, and $512-1-1,34-35 \mathrm{~cm}$ contain poorly to moderately preserved diatoms that are assigned to the Quaternary Coscinodiscus lentiginosus Zone of McCollum (1975). This zonal assignment places a maximum age of $620,000 \mathrm{yr}$. on these samples. Abundant and moderately preserved diatoms observed in Sample 5121-1, 64-65 cm include Rhizosolenia barboi, Cosmiodiscus insignis, Coscinodiscus vulnificus, Nitzschia weaveri and one specimen of $N$. interfrigidaria. This assemblage represents the $N$. interfrigidaria/C. vulnificus Zone and is correlative to the mid-Gauss Chronozone $(\sim 3.10-2.8$ Ma). Sample 512-1-1, 80-81 cm contains a mixed assemblage of early Pliocene and late Miocene diatoms which appears to represent the $N$. angulata Zone (Weaver, 1976) with numerous reworked (by drilling) late Miocene diatoms. Another sample, taken slightly lower in
Section $1(88-89 \mathrm{~cm})$, contains abundant and moderately preserved $N$. angulata, $N$. praeinterfrigidaria, $N$. reinholdii, Stephanopyxis turris, and Coscinodiscus marginatus. This sample contains rare reworked microfossils and is confidently correlated to the $N$. angulata Zone. The limited lower Pliocene stratigraphic range of this zone restricts the age of this sample, and probably of $512-1-1,80-81 \mathrm{~cm}$, to approximately 4.3 to $4.0 \mathrm{Ma}$ (Gilbert Magnetic Chron). Finally, Samples 512-1-1, 100$102 \mathrm{~cm}$ through $512-1, \mathrm{CC}$ contain a well-preserved assemblage of late Miocene diatoms, the most common of which include Denticulopsis lauta, D. hustedtii, D. dimorpha, and abundant Thalassiothrix spp. These latter samples are assigned to the upper Miocene D. hustedtii/D. lauta Zone of Weaver and Gombos (1981).

The diatom stratigraphy of Core 1 suggests the following sediment age, sedimentology, and hiatus relationships:

\begin{tabular}{|c|c|c|}
\hline Depth & Age & Sediment Type \\
\hline $0-36 \mathrm{~cm}$ & $<620,000$ yr. & $\begin{array}{l}\text { Diatomaceous to fora- } \\
\text { miniferal quartz sand }\end{array}$ \\
\hline Hiatus & $<620,000$ yr. -2.8 m.y. & \\
\hline $36-79 \mathrm{~cm}$ & - 2.8-3.1 m.y. & $\begin{array}{l}\text { Diatomaceous sandy } \\
\text { gravel }\end{array}$ \\
\hline Hiatus & $\sim 3.1-4.0$ m.y. & \\
\hline $79-93 \mathrm{~cm}$ & $\sim 4.0-4.3$ m.y. & $\begin{array}{l}\text { Muddy sandy diato- } \\
\text { maceous ooze }\end{array}$ \\
\hline Hiatus & $\sim 4.3-10.3$ m.y. & \\
\hline $93 \mathrm{~cm}-2.5 \mathrm{~m}$ & $\sim 10.3$ m.y. & $\begin{array}{l}\text { Diatomaceous ooze and } \\
\text { diatomaceous, nan- } \\
\text { nofossil ooze }\end{array}$ \\
\hline
\end{tabular}

Sample 512-2-1, 110-112 cm through Core 5,CC contain an assemblage indicative of the $N$. denticuloides Zone of Weaver and Gombos (1981). Among the common species present are Thalassiothrix spp., Nitzschia denticuloides, Denticulopsis dimorpha, D. lauta, D. hustedii, Rhizosolenia styliformis, Coscinodiscus marginatus, C. endoi, Brunia mirabilis, and Actinocyclus ingens. 
Table 2. Relative abundances of selected diatoms and silicoflagellates from the Middle Miocene to Quaternary of Hole 512.

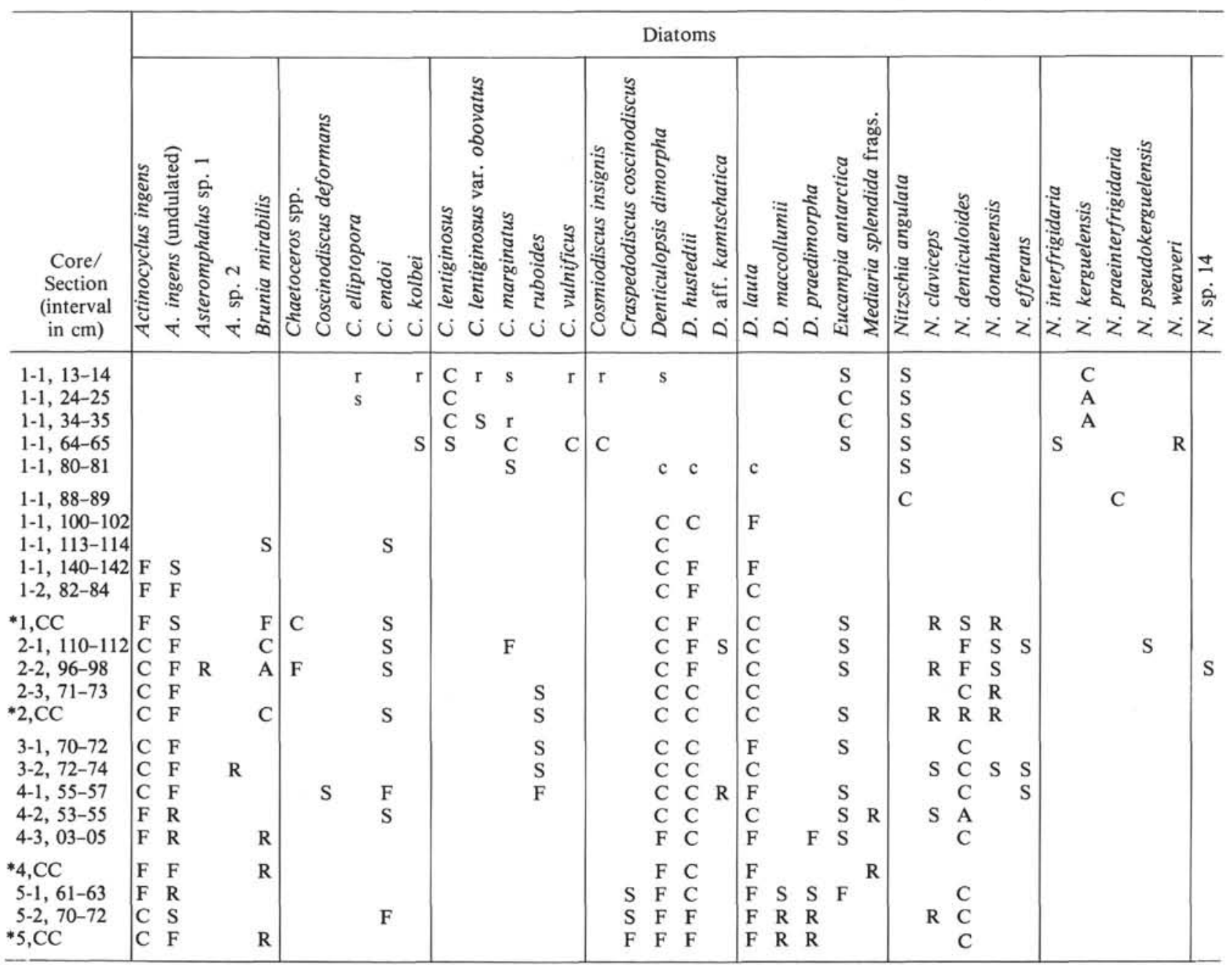

Note. * Indicates intervals where sieved fractions were examined. Other symbols are explained in Table 1.

The thinness of the upper Miocene Denticulopsis hustedtii/D. lauta Zone (between 512-1-1, $93 \mathrm{~cm}$ and 512$1, \mathrm{CC})$ suggests that another disconformity may exist between this zone and the underlying $N$. denticuloides Zone; however, diatom evidence suggests otherwise. First, the absence of Thalassiosira sp. 10 and the presence of $D$. dimorpha and sparse $N$. denticuloides indicate that only the lower portion of the $D$. hustedtii/D. lauta Zone is present in Cores 1 and 2. Secondly, the scarcity of $D$. maccollumii in Cores 2 through 5 limits this interval to the uppermost portion of the $N$. denticuloides Zone. Thus the section from 512-1-1, $93 \mathrm{~cm}$ through 512-5,CC contains the lower portion of the $D$. hustedtii/D. lauta Zone and the uppermost $N$. denticuloides Zone with a possible conformable boundary between $512-1, C C$ and $512-2-1,110-112 \mathrm{~cm}$. Correlation of the magnetic polarity sequence of this interval to the standard paleomagnetic time scale (Ledbetter, this volume) indicates that this interval represents most of paleomagnetic Chron 10 and upper Chron 11. The upper boundary of the $N$. denticuloides Zone approximates the first occurrence of Neogloboquadrina acostaensis in Sample 512-2-1, $106 \mathrm{~cm}$ (Thunell, pers. comm., 1982).
An unconformity between Cores $512-5$ and $512-6$ separates middle Miocene diatomaceous nannofossil ooze of the Nitzschia denticuloides Zone of Weaver and Gombos (1981) from middle Eocene siliceous nannofossil ooze. Gombos (this volume) describes the unique middle Eocene diatoms of this hole.

\section{Site 513 (Table 3, Figs. 8-10)}

Site $513\left(47^{\circ} 34.99^{\prime} \mathrm{S}, 24^{\circ} 38.40^{\prime} \mathrm{W} ; 4373 \mathrm{~m}\right)$ is located on the lower western flank of the Mid-Atlantic Ridge, near the southeastern margin of the Argentine Basin. Two holes were rotary drilled and continuously cored to basement at a sub-bottom depth of 387 meters. The first hole at Site 513 was drilled to a depth of 104.0 meters sub-bottom; however, sediment recovery below 56.5 meters was limited to Core $9(75.5-85.0 \mathrm{~m})$. The second hole, 513A, filled in the drilling gap of the first hole ( 56.6 to $75.5 \mathrm{~m}$ ) and then was continuously drilled to basement. This report describes only the Neogene diatoms of Hole 513 and Hole 513A, Cores 1-11. Early Miocene diatoms from Hole 513A, Cores 12-33, are described by Gombos and Ciesielski (this volume). 
Table 2. (Continued).

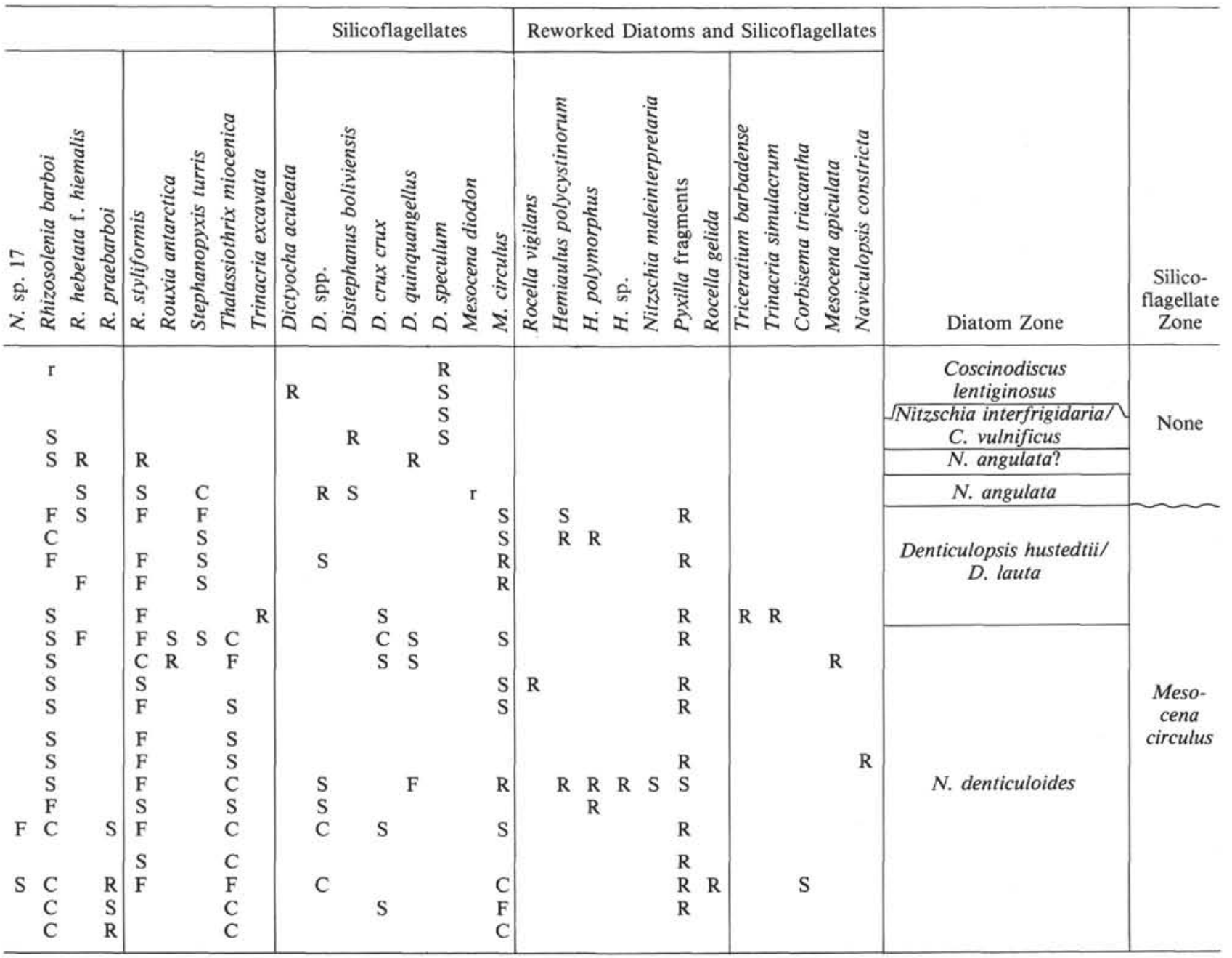

Diatoms are well represented throughout the entire lower Oligocene to Quaternary sequence of Holes 513 and 513A. In Pliocene-Quaternary sediments diatoms are common to abundant, diverse, and moderately preserved. Diatoms are common to abundant, poorly to moderately well preserved, and of moderate to high diversity in Miocene sediments.

Age determinations of Miocene-Quaternary sediments were made using the zonal scheme of McCollum (1975), as modified by Weaver (1976), Weaver and Gombos (1981), and Ciesielski (this report). Major diatom datums found within the lower Miocene-Quaternary of Holes 513 and 513A are given in Figures 8 and 9. Figure 8 presents a correlation of the Pliocene-Quaternary of Site 513 to magnetostratigraphy; a similar correlation of the upper Miocene of Hole 513 (Cores 5-11) is given in Figure 10.

Cores 1-6 of Hole 513 contain an apparently continuous sequence of the upper Pliocene-Quaternary. Within this interval the youngest eight zones of Ciesielski's revised diatom zonation (this chapter) are present. The Coscinodiscus lentiginosus Zone of the Brunhes Chron is present from the surface through 513-1-6, 115-117 $\mathrm{cm}$. The C. elliptopora/Actinocyclus ingens Zone of the lowermost Brunhes-upper Matuyama Chronozone occurs from 513-3-1, 45-47 cm through 513-4-2, 90-92 cm; thus the boundary between these two zones $(\sim 620,000$ y.B.P.) and the Brunhes/Matuyama Chronozone boundary (720,000 y.B.P.) probably falls in the unrecovered interval of Core 2. The mid-Matuyama Chronozone is represented between 513-4-3, 90-92 cm and 513-5-4, 5-7 cm where the Rhizosolenia barboi/Nitzschia kerguelensis Zone is encountered. Lower Matuyama Chronozone sediments are represented by the $C$. kolbei/R. barboi Zone and $C$. vulnificus Zone, which are found from 513-5-5, 2-4 cm to 513-6-1, 2-4 cm and at 513-6-2, 2-4 $\mathrm{cm}$ respectively.

Gauss Chronozone sediments are first encountered in Sample 513-6-2, 73-75 cm, which has been assigned to the Cosmiodiscus insignis Zone. The Matuyama/Gauss boundary, which occurs in the lowermost Coscinodiscus vulnificus Zone, thus probably occurs between 4 and $73 \mathrm{~cm}$ of Section 513-6-2. Samples 513-6-2, 73-75 cm through 513-6-4, 2-4 cm contain the Cosmiodiscus insignis Zone and the underlying $N$. weaveri Zone occurs only in Sample 513-6-5, 2-4 cm; both zones represent the upper normal-polarity interval of the Gauss Chronozone. The $N$. interfrigidaria/Coscinodiscus vulnificus 
Table 3. Relative abundances of selected diatoms from the late Miocene to Quaternary of Hole 513 and 513A.

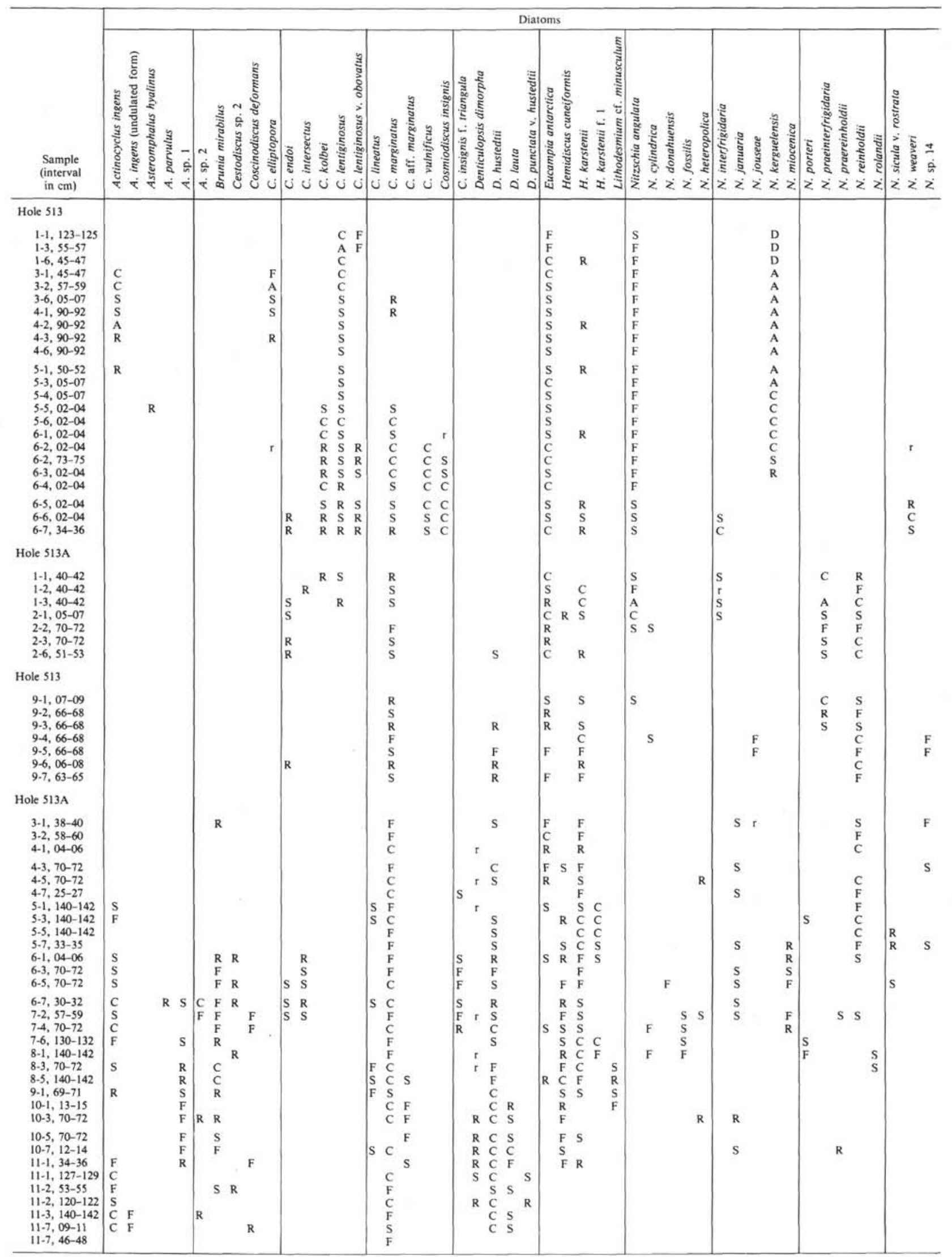

Note: Symbols are explained in Table 1. 
Table 3. (Continued).

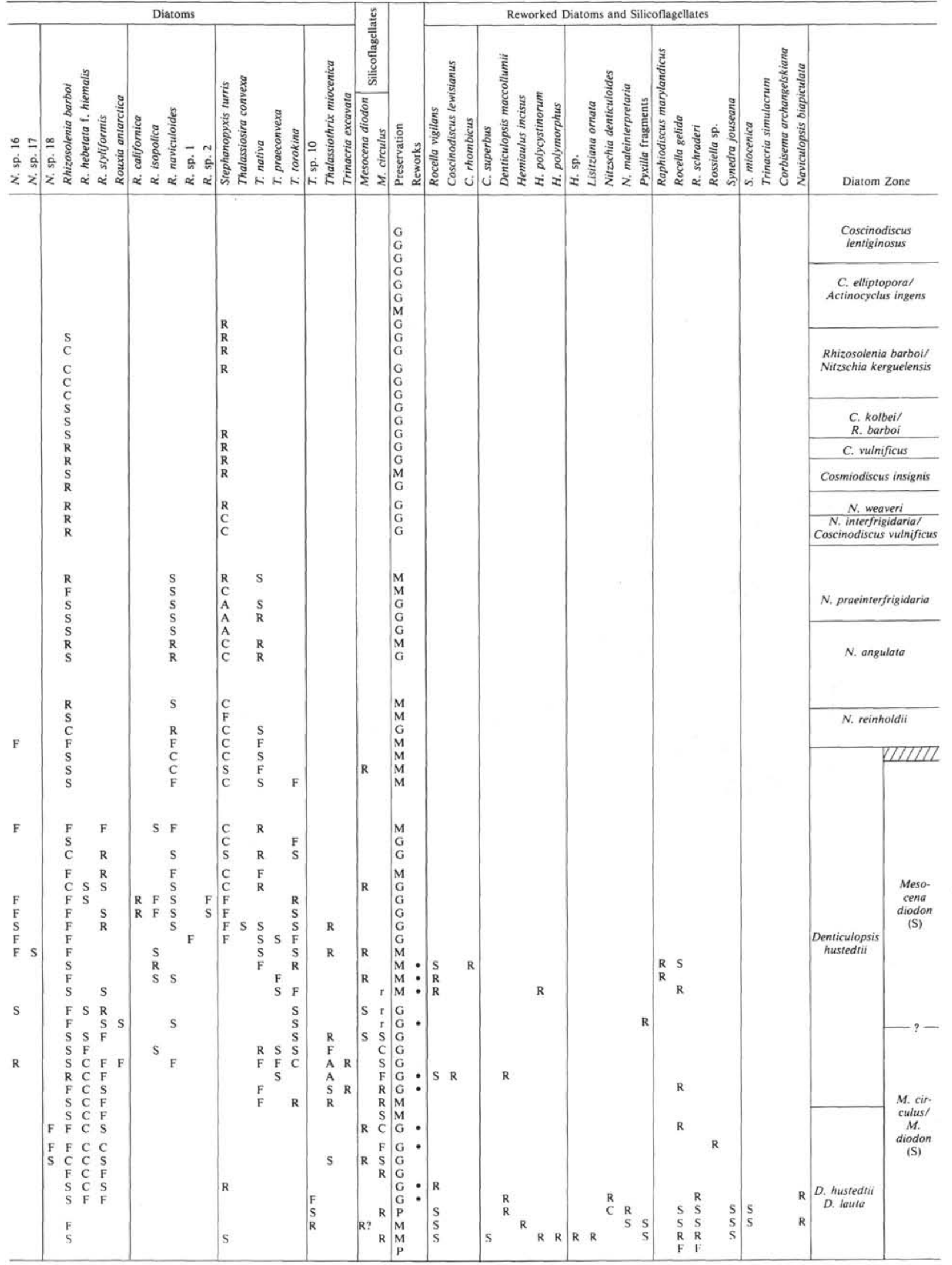




\section{P. F. CIESIELSKI}

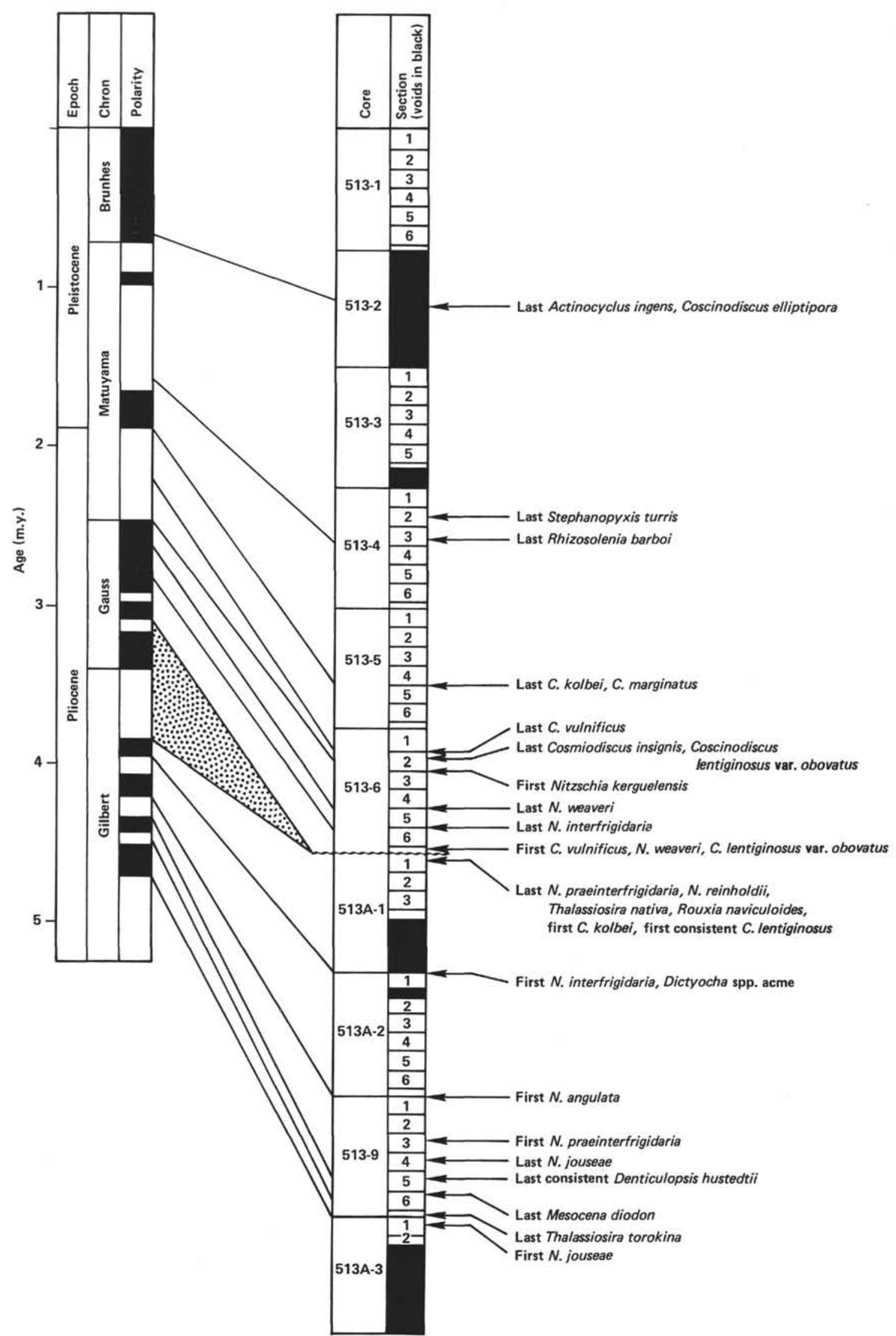

Figure 8. Positions of significant diatom and silicoflagellate datums in the Pliocene to Quaternary of Holes 513 and $513 \mathrm{~A}$ and their correlation to paleomagnetic stratigraphy. 


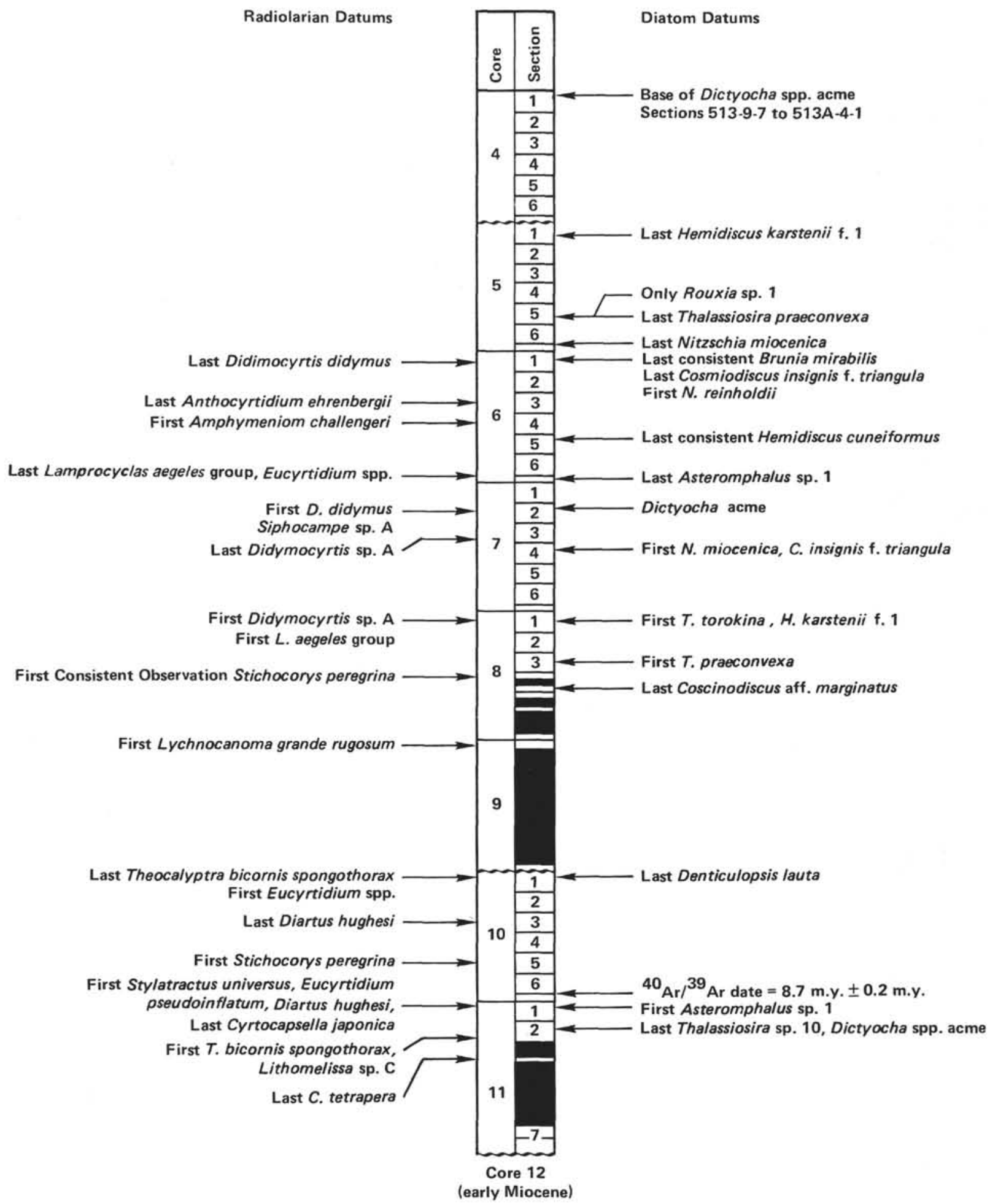

Figure 9. Positions of significant diatom and radiolarian datums in the upper Miocene of Hole 513A. Radiolarian datums from Weaver (this volume).

Zone is present between 513-6-6, 2-4 cm and 513-6-7, $34-36 \mathrm{~cm}$. This later zone is indicative of the mid-Gauss Chronozone, from the lower portion of the upper normal-polarity sequence to between the Kaena and Mammoth subchronozones.

No sediments were recovered from Cores 513-7 and 513-8; however, this interval (56.5-75.5 m) was partially recovered in Cores 513A-1 and 513A-2. The youngest sediment examined from Hole 513A (Sample 513A-1-1, $40-42 \mathrm{~cm}$ ) was assigned to the $N$. praeinterfrigidaria Zone of the Gilbert Chronozone. The $N$. interfrigidaria Zone is thus absent or restricted to the interval of less than one meter between samples examined from the base of Hole 513 and the top of Hole 513A. The pres- 


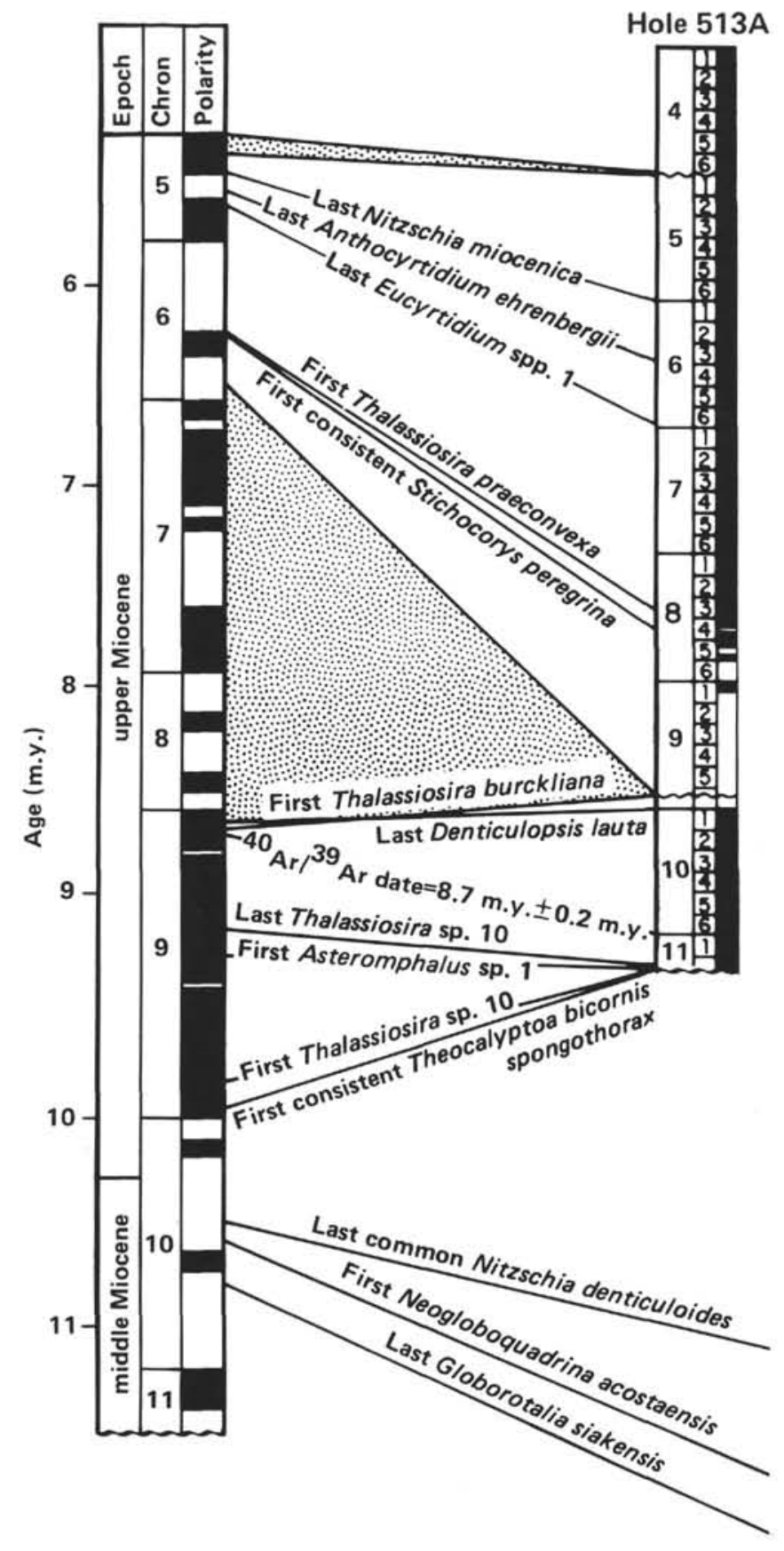

Figure 10. Correlation of selected upper Miocene diatom and radiolarian datums of Hole 513A to paleomagnetic stratigraphy. For a thorough discussion of this portion of Hole 513A and its correlation to other southern high-latitude DSDP sites see Ciesielski and Weaver (this volume). Radiolarian datums from Weaver (this volume).

ence of a hiatus between $513-6-7,34-36 \mathrm{~cm}$ and 513A-1$1,40-42 \mathrm{~cm}$ is also supported by numerous first and last species occurrences at these levels, including the last occurrence of $N$. praeinterfrigidaria, $N$. reinholdii, Rouxia naviculoides, and Thalassiosira nativa in Sample 513A-1-1, 40-42 cm, as well as the first occurrence of Cosmiodiscus insignis, $N$. weaveri, Coscinodiscus vulnificus, and C. lentiginosus f. obovatus in Sample 5136-7, 34-36 cm. This Pliocene hiatus represents the lower
Gauss Chronozone below the normal-polarity interval between the Kaena and Mammoth subchronozones and the Gilbert Chronozone above the Cochiti Subchronozone. The age of the sediment bracketing the disconformity, when calculated by assuming constant sedimentation rates from known datums above and below the disconformity, is 3.05 and $3.85 \mathrm{Ma}$, respectively. This calculated age is in agreement with diatom and radiolarian assemblages above and below the disconformity.

An alternative explanation for the Pliocene hiatus between Hole 513, Core 6 and Hole 513A, Core 1 is that the missing $N$. interfrigidaria Zone may be accounted for by an inaccurate sub-bottom depth estimate for the base of Hole 513 and the top of Hole 513A. This explanation seems unlikely, however, because the missing interval should be $10-20$ meters thick (if sedimentation rates were one-half to equal the prior $18.5 \mathrm{~m} / \mathrm{m}$.y. rate of sedimentation), and a depth error of more than a few meters seems unreasonable.

Sediments of the Gilbert Chronozone are present between 513A-1-1, 40-42 cm and 513A-4-7, 25-27 cm; the interval represents most of Gilbert from the base of the Cochiti Subchronozone to the lower Gilbert below the Thvera Subchronozone (Fig. 8). Diatom zones present within this interval include the $N$. praeinterfrigidaria Zone, 513A-1-1, 40-42 cm through 513A-2-1, 5-7 cm; the $N$. angulata Zone, $513 \mathrm{~A}-2-2,70-72 \mathrm{~cm}$ through 513-9-1, 7-9 cm; the $N$. reinholdii Zone, 513-9-2, 66-68 $\mathrm{cm}$ through 513-9-4, 66-68 cm; and the Denticulopsis hustedtii Zone, 513-9-5, 66-68 cm through 513A-4-7, 25-27 cm.

Diatom and radiolarian assemblages in Core 513A-5 indicate the presence of a hiatus between Cores 4 and 5 (Fig. 9). This hiatus spans an interval including the Miocene/Pliocene boundary (uppermost Chronozone 5 and lowermost Gilbert Chronozone) (Fig. 10). Samples 513A5-1, 140-142 cm through 513A-9-1, 69-71 cm represent the late Miocene portion of the D. hustedtii Zone. Diatom and radiolarian datums within this interval (Fig. 9) allow it to be correlated to Chronozones 5 and 6 (Fig. 10).

A third disconformity occurs at Site 513 , within a zone where no sediment was recovered between Sample 513A-9-1, 69-71 cm and 513A-10-1, 13-15 cm (Fig. 9). This disconformity separates the sediments of the $D$. hustedtii Zone above from the $D$. hustedtii/D. lauta Zone sediments found below. The missing interval includes lower Chronozone 6, Chronozone 7, and most or all of Chronozone 8.

The $D$. hustedtii/D. lauta Zone occurs between 513A$10-1,13-15 \mathrm{~cm}$ and $513 \mathrm{~A}-12-1,9-11 \mathrm{~cm}$. Age control for this interval was provided by a ${ }^{40} \mathrm{Ar} /{ }^{39} \mathrm{Ar}$ analysis of volcanic ash from Sample 513A-10-7, 10-13 cm (R. D. Dallmeyer, University of Georgia, pers. comm., 1981). The ${ }^{40} \mathrm{Ar} /{ }^{36} \mathrm{Ar}$ versus ${ }^{39} \mathrm{Ar} /{ }^{36} \mathrm{Ar}$ isochron age for the incremental gas analysis was 8.7 m.y. \pm 0.2 m.y. (Fig. $10)$, thus the interval represented at this site by the $D$. hustedtii/D. lauta Zone can be correlated to upper Chronozone 9 or lower Chronozone 8.

A major change occurs in the late Miocene diatom assemblage between Samples 513A-11-2, 53-55 cm and 
513A-11-2, 120-122 cm. Abundant middle Miocene and Oligocene diatoms are reworked in the upper Miocene sediments between $513 \mathrm{~A}-11-2,120-122 \mathrm{~cm}$ and $513 \mathrm{~A}$ $12-1,9-11 \mathrm{~cm}$. These reworked diatoms were apparently transported to the site by bottom currents from the nearby exposures of older sediment that are seen on seismic reflection profile records (Ciesielski and Weaver, this volume). Reworked middle Miocene diatoms include representatives of the upper $N$. maleinterpretaria Zone, Coscinodiscus lewisianus Zone, and $N$. denticuloides Zone. Reworked Oligocene diatoms come primarily from the lower Oligocene Pyxilla prolongata Group Zone and all four upper Oligocene zones of Gombos and Ciesielski (this volume).

The fourth and lowermost detected disconformity occurs between Samples 513A-12-1, 9-11 cm and 513A$12-1,123-125 \mathrm{~cm}$; separating the upper Miocene above from a lengthy and apparently continuous lower Oligocene-lower Miocene section. Eight diatom zones occur in Hole 513A between Sample 12-1, 123-125 cm and the chert and basalt sill encountered in Cores 34-36. Seven of these zones are described for the first time by Gombos and Ciesielski (this volume).

\section{Site 514 (Table 4)}

Site $514\left(46^{\circ} 02.77^{\prime} \mathrm{S}, 26^{\circ} 51.30^{\prime} \mathrm{W} ; 4318 \mathrm{~m}\right)$ is east of the Argentine Basin on the lower west flank of the MidAtlantic Ridge. A continuous Pliocene through Quaternary sequence of diatomaceous clays and muddy diatomaceous oozes was hydraulic piston cored to a sub-bottom depth of 150.8 meters. Site 514 is about $400 \mathrm{~km}$ north of the present-day position of the Polar Front and about $300 \mathrm{~km}$ north of Site 513 . A major objective at both sites was to determine the late Cenozoic history of the Polar Front.

Abundant and diverse diatom assemblages of early Pliocene to Quaternary age occur throughout all of Hole 514. This continuously cored HPC section is characterized by good preservation of siliceous microfossils, high sediment accumulation rates, nearly continuous deposition, and an excellent paleomagnetic record.

Site 514 and several piston cores were used to establish the revised diatom zonation of southern high-latitude sediments presented here. Eleven diatom zones are recognized in Hole 514. The stratigraphic occurrence of each zone is as follows: Samples 514-1-1, 47-49 cm through 514-3-1, 72-74 cm, Coscinodiscus lentiginosus Zone; 514-3-2, 70-72 cm through 514-5-4, 54-56 cm, $C$. elliptopora/Actinocyclus ingens Zone; 514-6-1, 77-79 $\mathrm{cm}$ through 514-6-2, 80-82 cm, Rhizosolenia barboi/ Nitzschia kerguelensis Zone; 514-6-3, 77-79 cm through 514-9-2, 70-72 cm, C. kolbei/R. barboi Zone; 514-9-3, 63-65 cm through 514-12-1, 50-52 cm, C. vulnificus Zone; 514-12-2, 26-28 cm through 514-15-2, 70-72 cm, Cosmiodiscus insignis Zone; 514-15-3, 70-72 cm through 514-19-1, 72-74 cm, $N$. weaveri Zone; 514-19-2, 72-74 $\mathrm{cm}$ through 514-25-1, 95-97 cm, N. interfrigidaria/Coscinodiscus vulnificus Zone; 514-26-1, 98-100 cm through 514-27-2, 84-86 cm, $N$. interfrigidaria Zone; 514-28-1, 90-92 cm through 514-32-1, 77-79 cm, $N$. praeinterfrig- idaria Zone; and 514-33-1, 75-77 cm through 514-35-3, $73-75 \mathrm{~cm}, N$. angulata Zone.

All index diatom species found in the subantarctic Hole 514 are also common to antarctic sediments of similar age (Ciesielski, 1978; Weaver and Gombos, 1981). The stratigraphic ranges of the zonal guide species of this site are also similar in the antarctic. Previous correlations of index diatom species to paleomagnetic stratigraphy elsewhere in the southern high latitudes (McCollum, 1975; Ciesielski, 1978; Weaver and Gombos, 1981; and Ciesielski, this chapter) are used to correlate the magnetic polarity sequence of Hole 514 to the standard paleomagnetic time scale (Table 4). A single hiatus is identified within the lower portion of the $N$. interfrigidaria Zone, between Samples 514-26-3, 54-56 $\mathrm{cm}$ and $514-27-1,84-86 \mathrm{~cm}$. The diatom assemblage and magnetic polarity record immediately above and below the disconformity indicate that the missing interval represents a portion of the Mammoth Subchronozone, the entire lower normal-polarity portion of the Gauss Chronozone, and most of the uppermost reversed-polarity portion of the Gilbert Chronozone ( 3.86-3.16 Ma).

Scattered occurrences of rare to few Denticulopsis hustedtii are reworked into Cores $25-30$ and Core 34 . Common to abundant reworked late Oligocene to earliest Miocene diatoms are found in upper Gauss Chronozone sediments of Core 19 , Section $1(20-22 \mathrm{~cm}$ and $72-74 \mathrm{~cm}$ ). Common reworked diatoms in Core 19 include Synedra jouseana, Hemiaulus tauris, Rossiella sp. A, Rocella gelida, $R$. vigilans, and Asterolampra affinis. Several of these reworked species have stratigraphic ranges restricted to the latest Oligocene-early Miocene $R$. vigilans through $R$. gelida Zones of Gombos and Ciesielski (this volume).

\section{TAXONOMIC REFERENCES}

Taxonomic references for all taxa recorded during this study are listed here, with species authors, one or more readily accessible references with descriptions and illustrations, and a plate reference for those species illustrated here.

Descriptions of New Taxa and Taxonomic Revision

\section{Genus COSCINODISCUS Ehrenberg (1838)}

Coscinodiscus lentiginosus var. obovatus (Castracane) Ciesielski n. comb.

(Plate 4, Figs. 6-8)

Coscinodiscus obovatus Castracane, 1886, p. 160, pl. 22, fig. 9.

Remarks. DeFelice (1979) discussed fully the morphology of Coscinodiscus obovatus and its similarity to $C$. lentiginosus. He suggested that the former species was an extinct Pliocene form of $C$. lentiginosus but did not formally establish it as such.

The range of $C$. obovatus in Leg 71 sediments adds to the evidence that this species is a variation of $C$. lentiginosus. $C$. obovatus is not extinct, as was previously thought, for it occurs sporadically in the Brunhes and Matuyama chronozones (Sites 511, 512, and 513). I have also noted the species in surface sediments of some Southern Ocean piston cores (unpublished data). The sporadic occurrences of $C$. obovatus within the Gauss, Matuyama, and Brunhes chronozones suggests that this species is an elliptical variation of $C$. lentiginosus; it is now formally named $C$. lentiginosus var. obovatus.

The earliest occurrence of the variety is within the Mammoth Subchronozone of the Gauss Chron. It occurs widely in mid-upper Gauss Chronozone sediments, whereas occurrences in younger sediments are sporadic and local in extent. 
Table 4. Relative abundances of selected diatoms and silicoflagellates of Hole 514.

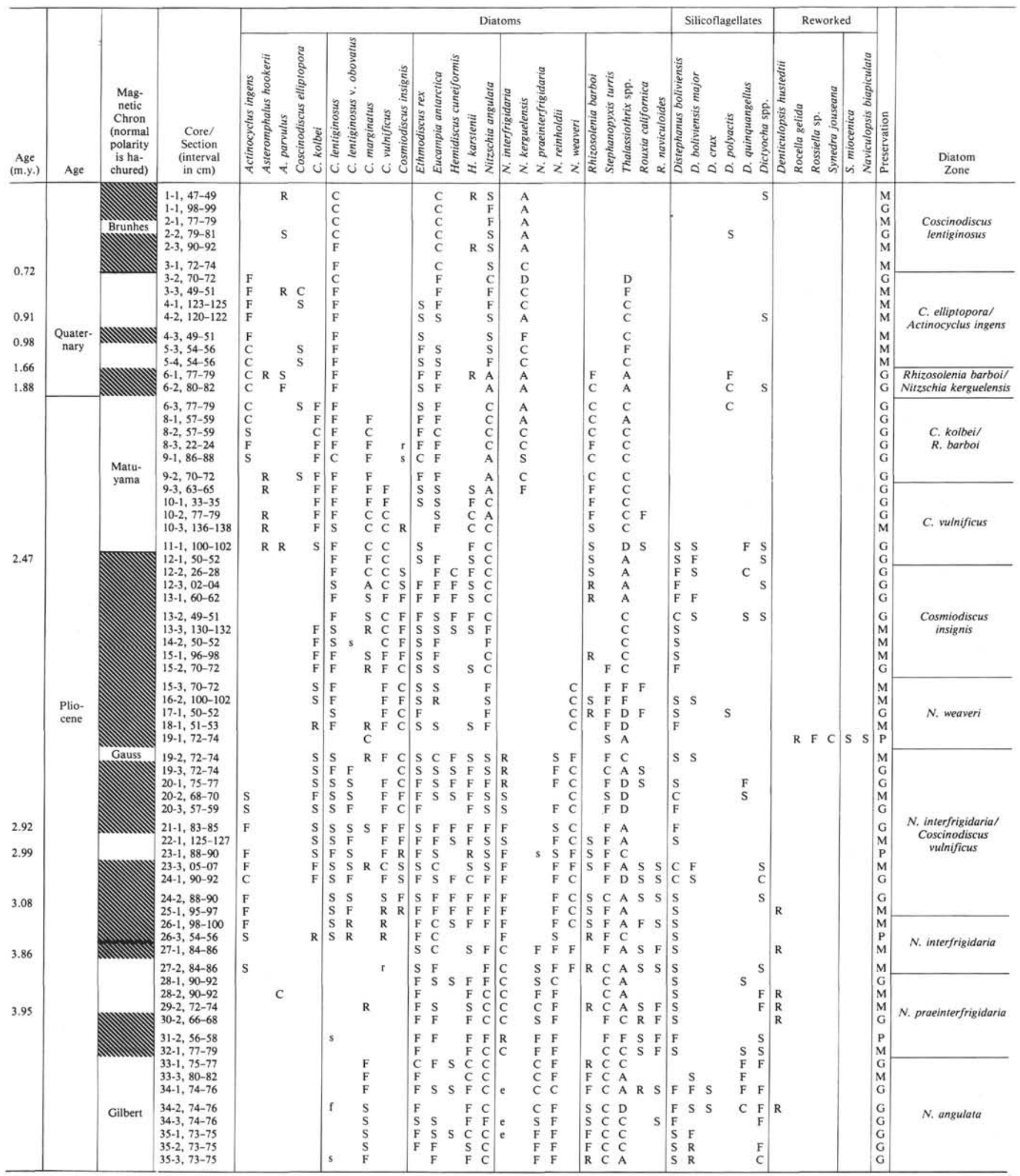

Note: "e" represents transitional form between $N$. praeinterfrigidaria and $N$. interfrigidaria. Other symbols are defined in Table 1. Magnetic polarity measurements by Salloway and Bloemendal (this volume). Ages of magnetic chrons and subchrons Dalrymple (1979) 
Genus NITZSCHIA Hassal (1854)

Nitzschia interfrigidaria McCollum, 1975, emend. Ciesielski, this chapter

(Plate 1, Figs. 11-18)

Nitzschia interfrigidaria McCollum, 1975, p. 535, pl. 9, figs. 7-9.

Discussion. McCollum's (1975) incomplete and partially inaccurate diagnosis of this species has resulted in some uncertainty over the concept of this species (Gombos, 1977; Schrader, 1976); therefore, Nitzschia interfrigidaria is emended here.

Description. Valves elliptical-linear, flat, broadly rounded apices; 28-75 $\mu \mathrm{m}$ long, 7-9 $\mu \mathrm{m}$ wide. Transapical ribs $9.5-12$ in $10 \mu \mathrm{m}$, nearly transapical parallel, straight or curved at the apices. In light microscope, transapical ribs are more strongly developed along the valve margin. In some specimens the transapical ribs are very indistinct toward the center of the valve, giving the valve surface a hyaline appearance. Intercostal membrane perforated by a single row of punctae which are unevenly spaced and variable in size, shape, and number. Wide spacing of punctae gives portions of the valve surface a hyaline appearance. Raphe marginal, keel distinct and punctate.

Remarks. This species is a member of the Nitzschia praeinterfrigidaria- $N$. interfrigidaria $-N$. weaveri lineage. Specimens of $N$. praeinterfrigidaria transitional to, but not included in $N$. interfrigidaria, are shown in Plate 2, Figs. 13-16. Specimens of $N$. interfrigidaria transitional to but not included in $N$. weaveri are shown in Plate 1, Figs. 17-18.

Lectotype. Plate 9, figure 8 of McCollum (1975). McCollum did not designate a holotype; therefore, this lectotype is selected from his original material. McCollum apparently did not deposit his specimens in a permanent, responsible institution; thus a neotype may have to be selected in the future.

Occurrence. The earliest occurrence of $N$. interfrigidaria in Southern Ocean sediments occurs between the base of the Cochiti Subchronozone and the top of the Nunivak Subchronozone of the Gilbert Chronozone. The last occurrence of the species is in the upper normalpolarity interval of the Gauss Chronozone.

\section{Nitzschia praeinterfrigidaria McCollum, 1975, emend. Ciesielski, this chapter}

(Plate 2, Figs. 1-8, 13-16; Plate 3, Fig. 5)

Nitzschia praeinterfrigidaria McCollum, 1975, p. 535, pl. 10, fig. 1.

Discussion. McCollum's (1975) incomplete diagnosis of this species has resulted in some uncertainty over the concept of the species (Gombos, 1976; Schrader, 1976); therefore, Nitzschia praeinterfrigidaria is emended here.

Description. Valves elliptical-linear, flat, broadly rounded apices; 34-76 $\mu \mathrm{m}$ long, 7-9 $\mu \mathrm{m}$ wide. Transapical ribs $9.5-10.5$ in $10 \mu \mathrm{m}$. One side of the valve nearly straight, the other more rounded. Transapical ribs distinct over the entire valve, may be transapical parallel but most commonly are inclined slightly over a portion of the valve surface and slightly curved at the poles. Intercostal membrane with a single row of punctae, unevenly spaced, with no large nonpunctate regions. Raphe marginal, canal raphe with distinct keel punctae.

Remarks. Nitzschia praeinterfrigidaria is the ancestor of $N$. interfrigidaria and $N$. weaveri. This species differs from $N$. interfrigidaria by its more completely punctate intercostal membrane and absence of hyaline areas on the valve surface. $N$. praeinterfrigidaria is also less symmetric: one side of the valve is generally more rounded than the other. McCollum's (1975) diagnosis of $N$. interfrigidaria states that "occasionally one side is slightly more curved than the other;"' however, his figures do not verify this claim. None of McCollum's figures of $N$. interfrigidaria exhibits this characteristic, whereas, his sole figure of $N$. praeinterfrigidaria does. The results of the present study clearly reveal that $N$. praeinterfrigidaria, not $N$. interfrigidaria, is characterized by having one side of the valve more rounded than the other. McCollum must have meant to attribute this characteristic to $N$. praeinterfrigidaria, but mistakenly attributed it to $N$. interfrigidaria.

McCollum (1975) figured only one specimen of $N$. praeinterfrigidaria, which is the holotype of the species even though it was not so designated. McCollum apparently did not deposit his holotype in a permanent, responsible institution; I do not now know where it is, and unless it can be located, it will be necessary to designate a neotype.
Occurrence. The first occurrence of $N$, praeinterfrigidaria is in the vicinity of the Sidufjall Subchronozone and its last occurrence is in the upper Gilbert Chronozone between the Cochiti Subchronozone and the Gilbert/Gauss boundary.

\section{Nitzschia weaveri Ciesielski, n. sp.}

(Plate 1, Figs. 1-10)

Description. Valves elliptical-linear, strongly silicified, flat, with rounded apices; 27-80 $\mu \mathrm{m}$ long, 6-9 $\mu \mathrm{m}$ wide. Transapical ribs, 1113.5 in $10 \mu \mathrm{m}$, transapical parallel, strongly expressed on the valve margin, indistinct away from the margin. One large circular to elliptical pore on the valve margin between distinct transapical ribs. Prominent, lanceolate, hyaline, middle area. Intercostal membrane usually nonperforate; punctae, when present, small; no more than 2-3 per valve. Raphe marginal, canal raphe with distinct keel punctae. Raphe rises close to valve surface near the apices.

Discussion. This species is the younger end member of the $N$. praeinterfrigidaria- $N$. interfrigidaria- $N$. weaveri evolutionary lineage. $N$. weaveri differs from its ancestor $N$. interfrigidaria by the total or near absence of punctae on the intercostal membrane. The gradual reduction in the abundance of punctae has been noticed in Pliocene sediments of Hole 514 and in numerous piston cores. Two specimens of $N$. interfrigidaria with reduced abundance of punctae are shown on Plate 1, Figs. 17-18.

Holotype. Plate 1, Figure 3, 33 $\mu \mathrm{m}$ long, $6 \mu \mathrm{m}$ wide, Sample 5136-6, $2-4 \mathrm{~cm}$. USNM No. 353318 .

Paratypes. Plate 1, Figures 1 and 2 (USNM No. 353319); Figures 4 and 5 (USNM No. 353320).

Occurrence. I have noted the species in sediments from all sectors of the Southern Ocean. Its latitudinal range extends from the subantarctic to the Ross Sea. Nitzschia weaveri has its lowest occurrence in the Cochiti Subchronozone of the Gilbert Chronozone and its highest occurrence is in the middle of the upper normal-polarity portion of the Gauss Chronozone.

\section{Taxonomic Notes and Illustration References}

The first citation is the original description of the species, the second is a more recent and accessible reference. Only the second citation is included in the reference list.

Actinocyclus ingens Rattray. Flat form, Schrader, 1973, pl. 18, figs.

2-4, 7; undulated form, Baldant and Barron, 1980, pl. 1, figs. 1-2. Asteromphalus hookeri Ehrenberg, 1844. Fenner et al., 1976, pp. 768 769 , pl. 4 , fig. 24 .

Asteromphalus hyalinus Karsten, 1905. Fenner et al., 1976, pl 4, figs. $17-19$.

Asteromphalus parvulus Karsten, 1905. Hustedt, 1958, pl. 8, fig. 91. Asteromphalus sp. 1 (Plate 6, Figs. 1-2, 6, 9). Cells discord, valves slightly convex, generally $65-95 \mu \mathrm{m}$ in diameter. Valve surface with a central hyaline space occupying two-fifths of the diameter; 9-13 rays divide the valve into equal sectors. All rays not of equal length; shorter rays with junction points marginal to the center. Areolated segments between elevated rim and outer region of the ray central expansion zone. Areolae pentagonal-hexagonal, arranged in tangential rows.

Asteromphalus sp. 2 Schrader, 1976, pl. 8, fig. 1.

Asteromphalus sp. 3 (Plate 6, Fig. 5). Occurs rarely in the late Miocene of Hole 513A.

Brunia mirabilis (Brun in Brun and Tempère) Tempère, 1890 (Plate 7, Figs. 1-2). Barron, 1975, p. 127, pl. 4, fig. 16. Synonyms: As Bruniopsis mirabilis (Brun) Karsten, referenced in Schrader, 1973, p. 702 , pl. 13 , fig. 16 , Gombos, 1977 , p. 592 , pl. 6 , fig. 4

Cestodiscus sp. 2 Schrader, 1976, p. 630, pl. 12, fig. 7. Coscinodiscus deformans Schrader, 1976, p. 630, pl. 11, figs. 1-2.

Coscinodiscus elliptopora Donahue. Gombos, 1977, pl. 3, figs. 1-3, 6; pl. 9, fig. 3.

Coscinodiscus endoi Kanaya. Schrader, 1973, pl. 8, figs. 1-6, 10, 15. Coscinodiscus kolbei Jousé. McCollum, 1975, pl. 4, figs. 7-9.

Coscinodiscus lentiginosus Janish in Schmidt et al., 1878. Gombos, 1976, pl. 3, figs. 4-5.

Coscinodiscus lewisianus Greville, 1866. McCollum, 1975, pl. 5, figs. 2-4. Reworked.

Coscinodiscus lineatus Ehrenberg, 1838. Hustedt, 1930, pp. 392-393, fig. 204. 
Coscinodiscus marginatus Ehrenberg, 1841. Hustedt, 1930, pp. 416418 , fig. 223.

Coscinodiscus sp. aff. C. marginatus Ehrenberg, of Schrader, 1976, pl. 10, fig. 3 .

Coscinodiscus rhombicus Castracane, 1886. Schrader, 1976, pl. 21, figs. 1-3, 5 .

Coscinodiscus ruboides Schrader, 1976, pl. 6, figs. 4, 8.

Coscinodiscus superbus Hardman in Rattray, 1899. Gombos and Ciesielski, this volume, Pl. 4, Figs. 1-8. Synonyms: as Cestodiscus pulchellus, Greville, 1866, p. 123, pl. 11, fig. 5; Cestodiscus robustus, Jouse, 1974, p. 345, pl. 1, figs. 14-15. Reworked.

Coscinodiscus vulnificus Gombos, 1977, pl. 4, Figs. 1-3, pl. 42, figs. 1-2 (Plate 6, Figs. 7-8).

Cosmiodiscus insignis Jousé, 1961. McCollum, 1975, pl. 8, fig. 5; Gombos, 1977, pl. 4, figs. 4-5.

Cosmiodiscus insignis f. triangula Jousé, 1977, pl. 79, fig. 2 (Plate 5, Figs. 1-10). This distinctive triangular form of Cosmiodiscus insignis is highly variable in size, ranging from $32 \mu \mathrm{m}$ (Figs. 1-2) to $98 \mu \mathrm{m}$ (Figs. 7-8). Its first occurrence is in the upper reversed portion of Chronozone 6 and its last occurrence is in the lowermost Gilbert Chronozone, below the Thvera Subchronozone.

Cosmiodiscus intersectus (Brun) Jousé, 1961, p. 68, pl. 2, figs. 9-10; Koizumi, 1973, p. 832, pl. 4, figs. 12-13.

Craspedodiscus coscinodiscus Ehrenberg, 1884. Kanaya, 1971, p. 555 , pl. 40.4, figs. 1-3; Schrader, 1974, p. 541.

Denticulopsis dimorpha (Schrader) Simonsen, 1979. Schrader, 1973, p. 704 , pl. 1, figs. 28-34, 36-47; Barron, 1975, p. 138, pl. 8, fig. 7 .

Denticulopsis hustedtii (Simonsen and Kanaya) Simonsen, 1979. Schrader, 1973, pl. 2, figs. 28-34, 36-47.

Denticulopsis aff. kamtschatica (Zabelina) Simonsen, 1979, of Schrader, 1976 , p. 632 , pl. 4 , fig. 18

Denticulopsis lauta (Bailey) Simonsen, 1979. Schrader, 1973, pl. 2, figs. 14-24.

Denticulopsis maccollumii Simonsen, 1979. Schrader, 1976, pl. 4, figs. $3,22-23,25$.

Denticulopsis praedimorpha (Akiba) Simonsen, 1979. Barron, 1980, pl. 1, figs. 18-20.

Denticulopsis punctata var. hustedtii (Schrader) Simonsen, 1979. Schrader, 1973, pl. 1, figs. 23-24.

Ethmodiscus rex (Rattray) Hendey, 1953, pp. 51-57, pl. 1, figs. 1-6, pl. 2, figs. 1-3.

Eucampia antarctica Castracane, 1886. Fenner et al., 1976, p. 774, pl. 5, figs. 7-9; DeFelice and Wise, 1981, p. 62, pl. 5, figs. 7-9.

Hemiaulus incisus Hajós, 1976, p. 829, pl. 23, figs. 4-9; Gombos, 1976, p. 594, pl. 15, fig. 3. Synonyms: Hemiaulus kittonii Schmidt, 1888, pl. 142, fig. 11; Hemiaulus sp. 1 McCollum, 1975, p. 535, pl. 9, fig. 2. Reworked.

Hemiaulus polycystinorum Ehrenberg, 1854. Fenner, 1979, p. 521, pl. 21 , figs. $13-14$; pl. 22 , figs. $4-5,7-10$; pl. 23 , figs, 1-4. Reworked.

Hemiaulus polymorphus Grunow, 1884. Fenner, 1979, p. 522, pl. 21, fig. 11 ; pl. 23 , figs. $10-11$; pl. 22, fig. 13. Reworked

Hemidiscus cuneiformis Wallich, 1860. Schrader, 1973, pl. 24, fig. 14.

Hemidiscus karstenii Jousé, 1962. Abbott, 1972, pp. 110-112, pl. 1, figs. D-F.

Hemidiscus karstenii f. 1 (Plate 4, Figs. 2-5). This form of Hemidiscus karstenii is characterized by the presence of widely spaced areolae in the central portion of the valve. Maximum valve dimension is generally $65-75 \mu \mathrm{m}$. This form is common only in sediments of Chronozone 5 and upper Chronozone 6. Pliocene-Pleistocene specimens are smaller, more elliptical, and more completely areolated in the valve center.

Hemiaulus sp. Gombos and Ciesielski, this volume, Plate 20, Figures 7-9. Reworked.

Lithodesmium cf. minusculum Grunow in Van Heurck, 1883. Schrader, 1973 , p. 706 , pl. 12 , figs. 7 (?), 15, 17; Barron, 1975, p. 19, pl. 10 , fig. 3. (Plate 6, Figs. 3-4). In the North Pacific, Schrader (1973) found this species in NPD Zones XI-XV, which he correlated indirectly to upper magnetic Chron 7 through the Thvera Subchron of the Gilbert Chron. In the present study the species was found only in Hole 513A, in Samples 513A-8-3, 70-72 cm through 513A-10-1, 13-15 cm, correlative to latest Chron 9 through mid-Chron 6 .

Lizitziana ornata Jousé, 1978, pp. 47-48, pl. 10, figs. 1-4; Gombos and Ciesielski, this volume, Plate 18, Figures 1-4. Synonym: Triceratium cruciforme Schmidt, 1887, pl. 77, fig. 41. Reworked.
Mediaria splendida Sheshukova-Poretzkaya, 1962. Schrader, 1973, pl. 3, figs. 14-15.

Nitzschia angulata (O'Meara) Hasle, 1972. Hasle, 1965, pl. 1, fig. 6; pl. 4, fig. 19; pl. 6, fig. 5; pl. 8, fig. 11; pl. 9, figs. 1-6; pl. 10, figs. 2-6.

Nitzschia claviceps Schrader, 1976, p. 633, pl. 2, figs. 2, 4.

Nitzschia clementia Gombos, 1977, p. 595, pl. 8, figs. 18-19.

Nitzschia cylindrica Burckle, 1972, pp. 239-240, pl. 2, figs. 1-6; Schrader, 1973, p. 707, pl. 5, figs. 27, 32-33.

Nitzschia denticuloides Schrader, 1976, pl. 3, figs. 7-8, 10, 12, 18-24; pl. 15 , fig. 22.

Nitzschia donahuensis Schrader, 1976, p. 633, pl. 2, fig. 30

Nitzschia efferans Schrader, 1976, p. 633, pl. 2, figs. 1, 3, 5-7.

Nitzschia fossilis (Frenguelli) Kanaya in Kanaya and Koizumi, 1970. Schrader, 1973, pl. 4, figs. 4, 5, 9-11, 24-25.

Nitzschia heteropolica Schrader, 1973, pl. 26, figs. 1-2.

Nitzschia januaria Schrader, 1976, p. 634, pl. 2, figs. 25-29.

Nitzschia jouseae Burckle, 1972. Schrader, 1974, pl. 7, figs. 14-23.

Nitzschia kerguelensis (O’Meara) Hasle, 1972. Hasle, 1968, figs. 1, 2, 7-9.

Nitzschia maleinterpretaria Schrader, 1976, p. 634, pl. 2, figs. 9, 1119, 21, 24. Reworked.

Nitzschia miocenica Burckle, 1972, pp. 240-241, pl. 2, figs. 10-15 (Plate 2, Figs. 9-12).

Nitzschia porteri Frenguelli sensu Burckle, 1972, pl. 2, fig. 16.

Nitzschia praereinholdii Schrader, 1973, pl. 5, figs. 20, 23-26.

Nitzschia pseudokerguelensis Schrader, 1976, p. 634, pl. 15, figs. 1315.

Nitzschia reinholdii Kanaya sensu Koizumi. Schrader, 1973, pl. 4, figs. 12-16; pl. 5, figs. 1-9.

Nitzschia rolandii Schrader, 1973, p. 708, pl. 5, fig. 31; pl. 26, figs. 3-4.

Nitzschia sicula v. rostrata Hustedt, 1958, p. 180, pl. 11, figs. 128132; Schrader, 1976, p. 634 , pl. 2, fig. 31.

Nitzschia sp. 14 Schrader, 1976 , p. 634 , pl. 2, figs. 8, 36 .

Nitzschia sp. 16 Schrader, 1976, p. 634, pl. 2, fig. 37.

Nitzschia sp. 17 Schrader, 1976, p. 634, pl. 3, figs. 13-15, 17; pl. 2 , fig. 10.

Nitzschia sp. 18 Schrader, 1976, p. 634, pl. 15, fig. 19.

Pyxilla fragments. Only reworked fragments of this genus were found in Neogene sediments.

Raphiodiscus marylandicus Christian, 1887. Schrader, 1973, p. 708, pl. 22, fig. 7; Andrews, 1974, p. 232, pls. 1-5, figs. 1-29.

Rhizosolenia barboi Brun, 1894. Donahue, 1970, p. 136; Schrader, 1976 , p. 635 , pl. 9, figs. 11-13.

Rhizosolenia hebetata f. hiemalis Grun, 1904. Hustedt, 1930, pp. 590 592, fig. 337; Schrader, 1973, p. 709, pl. 9, figs. 11, 13-17, 19-21, $24,25$.

Rhizosolenia praebarboi Schrader, 1973, pp. 709-710, pl. 24, figs. 1-

Rhizosolenia styliformis Brightwell, 1858. Schrader, 1973, p. 710, pl. 10 , figs. $1,18-21$.

Rocella gelida (Mann) Bukry, 1978, p. 788, pl. 5, figs. 1-13. Reworked; this heavily silicified species is one of the most commonly reworked species in Southern Ocean sediments.

Rocella schraderia Bukry, 1978, p. 788, pl. 6, figs. 1-10; pl. 7, fig. 1. Reworked.

Rocella vigilans (Schmidt) Fenner, in press. Gombos and Ciesielski, this volume, Plate 6, Figures 7-10; pl. 26, fig. 2. Reworked.

Rossiella sp. Gombos and Ciesielski, this volume, Plate 24, Figures 12. Synonym: Bogorovia veniamini Jousé in Gombos, 1977, p. 593, pl. 1, figs. 6-7; pl. 12, figs. 1-2, 4. Reworked.

Rouxia antarctica Heiden and Kolbe, 1928. Gombos, 1977, p. 596, pl. 7, fig. 12; Schrader, 1976, p. 635, pl. 5, figs. 1-8.

Rouxia californica M. Peragallo in Tempère and Peragallo, 1910. Schrader, 1976, p. 635, pl. 5, fig. 21; Gombos, 1977, p. 596, pl. 7, fig. 13.

Rouxia isopolica Schrader, 1976, p. 635, pl. 5, figs. 9, 14-15, 20.

Rouxia naviculoides Schrader, 1973, p. 710, pl. 3, figs. 27-32; Gombos, 1977 , p. 597 , pl. 7 , figs. $10-11$.

Rouxia sp. 1 (Plate 2, Figs. 17-20). Valves heteropolar-elliptical, 45$55 \mu \mathrm{m}$ long, $11.5 \mu \mathrm{m}$ maximum width. One apex rounded, the other cuneate; one apex 1 to $1.5 \mu \mathrm{m}$ closer to the raphe than the other. Raphe bars well developed with a subrectangular depressed central area, pole fields with a sharp triangular hyaline area. Valve 
striate with 9 to 9.5 in $10 \mu \mathrm{m}$, transapical over the middle part of the valve and bent slightly toward the apices. Transapical striae faintly punctuate, 4 to 5 within one striae. Striae crossed by two apical lines, one faint.

Rouxia sp. 2 (Plate 2, Figs. 21-22). Valves linear with rounded apices, 60-70 $\mu \mathrm{m}$ long, $9 \mu \mathrm{m}$ maximum width. Rudimentary raphe bars, widely separated, $16-18 \mu \mathrm{m}$ long. Transapical ribs 8 to 9 in $10 \mu \mathrm{m}$, transapical parallel. Marginal apical ribs parallel to valve margin. Rectangular central area 3-4 $\mu \mathrm{m}$ wide, narrow tapering apical areas. Inner pores interior to transapical ribs. Valve structure isopolar.

Stephanopyxis "turris"' (Greville and Arn.) Ralfs in Pritchard, 1861. Hustedt, 1930, pp. 304-305, fig. 140; Schrader, 1976, p. 636, pl. 13 , fig. 7.

Synedra jouseana Sheshukova-Poretzkaya. Schrader, 1973, pl. 23, figs. 21-23, 25, 38. Reworked.

Synedra miocenica Schrader, 1976, p. 636, pl. 1, fig. 1. Reworked.

Thalassiosira convexa Mikhina. Schrader, 1974, pl. 2, figs. 1-5, 1013.

Thalassiosira nativa Sheshukova-Poretzkaya, sensu Koizumi, 1975b, pl. 2, fig. 9; Koizumi, 1975a, pl. 4, figs. 21-22.

Thalassiosira praeconvexa Burckle, 1972, p. 242, pl. 2, figs. 7-9; Schrader, 1973, p. 712 , pl. 11, figs. 10-15.

Thalassiosira torokina Brady, 1977, pp. 122-123, figs. 1-5 (Plate 7, Figs. 3-6).

Thalassiosira sp. 10 Schrader, 1976, p. 637, pl. 15, figs. 6-8.

Thalassiothrix miocenica Schrader, 1973, p. 713, pl. 23, figs. 2-5.

Triceratium barbadense Greville, 1861. Kanaya, 1957, pp. 100-101, pl. 7, figs. 1-4. Reworked.

Trinacria excavata Heiberg, 1863. McCollum, 1975, p. 536, pl. 15, figs. 1-2; Gombos, 1977, p. 599, pl. 37, fig. 6.

Trinacria simulacrum Grove and Sturt, 1887. Gombos, 1977, p. 599, pl. 35 , figs. 1-2, 4; pl. 36, figs. 1-4. Reworked.

\section{REFERENCES}

Abbott, W. H., 1972. Vertical and lateral patterns of diatomaceous ooze found between Australia and Antarctica [Ph.D. dissert.). University of South Carolina, Columbia.

Barron, J. A., 1975. Late Miocene-early Pliocene marine diatoms from southern California. Palaeontographica, B, 151:97-170.

1980 , Lower Miocene to Quaternary diatom biostratigraphy of DSDP Leg 57, off northeastern Japan, Deep Sea Drilling Project. In Scientific Party, et al., Init. Repts. DSDP, 56, 57, Pt. 2: Washington (U.S. Govt. Printing Office), 641-686.

Brady, H. T., 1977. Thalassiosira torokina n.sp. (diatom) and its significance in Late Cenozoic biostratigraphy. Antarct. J. U.S., 12: 122-123.

Bukry, D., 1978. Cenozoic silicoflagellate and coccolith stratigraphy, northwestern Atlantic Ocean, Deep Sea Drilling Project, Leg 43. In Benson, W. E., Sheridan, R. E., et al., Init. Repts. DSDP, 44: Washington (U.S. Govt. Printing Office), 775-805.

Burckle, L. H., 1972. Late Cenozoic planktonic diatom zones from the eastern equatorial Pacific. Nova Hedwigia Beih., 39:217-246.

Ciesielski, P. F., 1975. Biostratigraphy and paleoecology of Neogene and Oligocene silicoflagellates from cores recovered during Antarctic Leg 28, Deep Sea Drilling Project. In Hayes, D. E., Frakes, L. A., et al., Init. Repts. DSDP, 28: Washington (U.S. Govt. Printing Office), 625-692.

1978. The Maurice Ewing Bank of the Malvinas (Falkland) Plateau: Depositional and erosional history and its paleoenvironmental implications [Ph.D. dissert.]. Florida State University, Tallahassee.

1980. On the age of Neogene deposits at Site 329 (DSDP, Leg 36): Discussion. Rev. Espan. Micropaleontol., 12(1):87-89.

Ciesielski, P. F., Ledbetter, M. T., and Ellwood, B. B., 1982. The development of Antarctic glaciation and the Neogene paleoenvironment of the Maurice Ewing Bank. Mar. Geol., 46:1-51.

Defelice, D. R., and Wise, S. W., Jr., 1981. Surface lithofacies, biofacies, and diatom diversity patterns as models for delineation of climatic change in the southeast Atlantic Ocean. Mar. Micropaleontol., 6:29-70.

Donahue, J. G., 1970. Pleistocene diatoms as climatic indicators in North Pacific sediments. Geol. Soc. Am. Mem. 126:121.

Fenner, J., 1979. Cenozoic diatom biostratigraphy of the equatorial and southern Atlantic Ocean. In Supko, P. R., Perch-Nielsen, K., et al., Init. Repts. DSDP, Suppl. to Vols. 38, 39, 40, and 41: Washington (U.S. Govt. Printing Office), 491-623.

Fenner, J., Schrader, H.-T., and Wienigk, H., 1976. Diatom phytoplankton studies in the Southern Pacific Ocean, composition and correlation to the Antarctic Convergence and its paleoecological significance. In Hollister, C. D., Craddock, C., et al., Init. Repts. DSDP, 35: Washington (U.S. Govt. Printing Office), 757-813.

Gombos, A. M., Jr., 1977. Paleogene and Neogene diatoms from the Falkland Plateau and Malvinas Outer Basin: Leg 36, Deep Sea Drilling Project. In Barker, P. F., Dalziel, I. W. D., et al., Init. Repts. DSDP, 36: Washington (U.S. Govt. Printing Office), 575-687.

Gordon, A. L., Georgi, D. T., and Taylor, H. W., 1977. Antarctic Polar Front Zone in the Western Scotia Sea, Summer 1975. Phys. Oceanogr., 7:309-328.

Hajós, M., 1976. Upper Eocene and lower Oligocene Diatomaceae, Archaeomonadaceae and Silicoflagellatae in southwestern Pacific sediments, DSDP Leg 29. In Hollister, C. D., Craddock, C., et al., Init. Repts. DSDP, 35: Washington (U.S. Govt. Printing Office), 817-883.

Hasle, G., 1965. Nitzschia and Fragilariopsis, species studied in the light and electron microscopes. III. The genus Fragilariopsis. Skr. Nor. Videnskaps-Akad I. Mat.-Naturvidensk. Kl., 21:1-49.

1968. Observation on the marine diatom Fragilariopsis kerguelensis (O'Meara) Hust. in the scanning electron microscope. Nytt. Mag. Bot., 15:205-208.

Hendey, N. I., and Wiseman, D. H., 1953. The significance and diatom content of a deep-sea floor sample from the neighborhood of the greatest oceanic depth. Deep-Sea Res., 1:47-59.

Hustedt, F., 1930. Die Kieselalgen Deutschland, Osterreichs, und der Schweiz mit Berucksichtigung der ubrigen Lander Europas zowie der angrenzenden Meeresgebiete. In Rabenhorst, L. (Ed.), Kryptogamen-Flora von Deutschland, Osterreich und der Schweiz. Vol. 7, Pt. 1: Leipzig (Akademische Verlags gesellschaft).

1958. Diatomeen aus der Antarktik und dem Sudatlantik: Deutsche Antarktische Exped., 2:103.

Jousé, A. P., 1961. Miocene and Pliocene marine diatoms from the Far East. Akad Nauk SSSR, Bot. Inst. In. V. L. Komarova, Otd. Sporov. Rast., Bot. Mat. 14:59-70.

(Ed.), 1977. Atlas of Microorganisms in Bottom Sediments of the Oceans: Moscow (Nauka). (In Russian)

1978. New fossil genus of diatoms (Lisitzinia [Bacillariophyta]). Marskaya mikropaleontologiya Moscow, pp. 47-48.

Kanaya, T., 1957. Eocene diatom assemblages from the Kellogg and "Sidney" shales, Mt. Diablo Area, California. Sci. Rep. Tohoku Univ., Ser. 2 (Geol.), 28:27-124.

1971. Some aspects of pre-Quaternary diatoms in the ocean. In Funnel, B. M., and Riedel, W. R., (Eds.), Micropaleontology of the Oceans: Cambridge (Cambridge University Press).

Koizumi, I., 1975a. Neogene diatoms from the western margin of the Pacific Ocean, Leg 31, Deep Sea Drilling Project. In Karig, D. E., Ingle, J. C., Jr., et al., Init. Repts. DSDP, 31: Washington (U.S. Govt. Printing Office), 779-819.

1975b. Late Cenozoic diatom biostratigraphy in the circumNorth Pacific region. Geol. Soc. Japan J., 81(no. 10):611-627.

1977. Diatom biostratigraphy in the North Pacific region. Proceedings of the First International Congress on Pacific Neogene Stratigraphy: Tokyo (Kaiyo Shuppan), pp. 235-253.

Ledbetter, M. T., and Ciesielski, P. F., 1982. Bottom current erosion in the South Atlantic sector of the Southern Ocean. Mar. Geol., 46:329-341.

McCollum, D. W., 1975. Diatom stratigraphy of the Southern Ocean. In Hayes, D. E., and Frakes, L. A., et al., Init. Repts. DSDP, 28: Washington (U.S. Govt. Printing Office), 515-571.

Mankinen, E. A., and Dalrymple, G. B., 1979. Revised geomagnetic polarity time scale for the interval 0-5 m.y.b.p. J. Geophys. Res., 84(B2):615-626.

Opdyke, N. D., Burckle, L. H., and Todd, A., 1974. The extension of the magnetic time scale in sediments of the central Pacific Ocean. Earth Planet. Sci. Lett., 22:300-306.

Osborn, N. I., Ciesielski, P. F., and Ledbetter, M. T., in press. Disconformities and paleoceanography in the Southwest Indian Ocean during the last 5.4 million years. Geol. Soc. Am. Bull.

Ryan, W. B. F., Cita, M. B., Rawson, M., Burckle, L. H., and Saito, T., 1974. A paleomagnetic assignment of Neogene stage bound- 


\section{P. F. CIESIELSKI}

aries and the development of isochronous datum planes between the Mediterranean, the Pacific, and Indian Oceans in order to investigate the response of the world ocean to the Mediterranean "salinity crisis." Riv. Ital. Paleontol., 80:631-688.

Schrader, H.-J., 1973. Cenozoic diatoms from the northeast Pacific, Leg 18. In Kulm, L. D., von Huene, R., et al., Init. Repts. DSDP, 18: Washington (U.S. Govt. Printing Office), 673-797.

1974. Cenozoic marine planktonic diatom stratigraphy of the tropical Indian Ocean. In Fisher, R. L., Bunce, E. T., et al., Init. Repts. DSDP, 24: Washington (U.S. Govt. Printing Office), 887-967.

1976. Cenozoic planktonic diatom biostratigraphy of the Southern Ocean. In Hollister, C. D., Craddock, C., et al., Init. Repts. DSDP, 35: Washington (U.S. Govt. Printing Office), 605-671.

Simonsen, R., 1979. The diatom systems: Ideas on phylogeny. Bacillaria, 2:9-71.
Weaver, F. M., 1976. Late Miocene and Pliocene radiolarian paleobiogeography and biostratigraphy of the Southern Ocean [Ph.D. dissert.]. Florida State University, Tallahassee.

Weaver, F. M., and Gombos, A. M., 1981. Southern high latitude diatom biostratigraphy. In Warme, T. E., Douglas, R. C., and Winterer, E. L., (Eds.), The Deep Sea Drilling Project: A Decade of Progress. Soc. Econ. Paleont. Mineral., Spec. Publ., 32:445-470.

\section{ACKNOWLEDGMENTS}

I thank Dr. William H. Abbott of Mobil Exploration and Producing Services, Inc., and Dr. Fred M. Weaver of Exxon Production Research for their critical review of the manuscript. Ms. Barbara Daniel drafted the text figures. Financial support for this research was provided by NSF Grant DPP-811347 to M. T. Ledbetter and P. F. Ciesielski. 

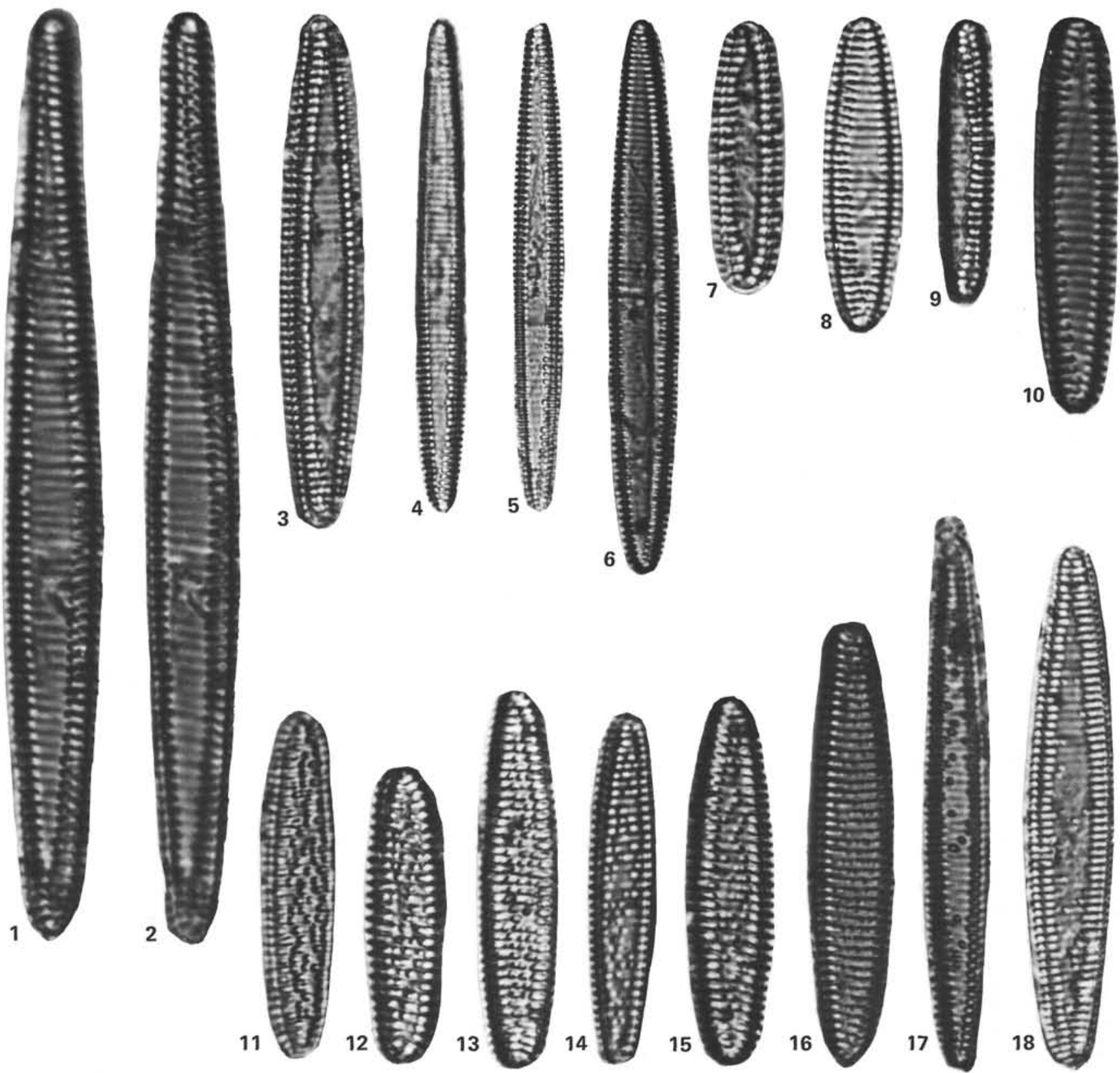

Plate 1. (All specimens magnified $\times 1500$ unless otherwise indicated.) 1-10. Nitzschia weaveri $\mathrm{n} . \mathrm{sp} .,(1-2)$ paratype, Sample 514-24-2, 89-91 $\mathrm{cm}$,

(3) holotype, Sample 513-6-6, 2-4 cm, (4-5) paratype, $\times 1000$, Sample 514-24-2, 89-91 cm, (6) $\times 1200$, Sample 513-6-6, 2-4 cm, (7-8) Sample 514-16-2, 100-102 cm, (9) Sample 513-6-6, 2-4 cm, (10) Sample 514-16-2, 100-102 cm. 11-18. Nitzschia interfrigidaria, (11) Sample 514-28-1, 90-92 cm, (12) Sample 514-30-2, 66-68 cm, (13) Sample 514-29-1, 72-74 cm, (14) Sample 514-28-1, 90-92 cm, (15) Sample 514-28-1, 90-92 cm, (16) Sample 514-19-3, 72-74 cm, (17) $\times 1000$, Sample 514-28-1, 90-92 cm, (18) Sample 514-16-2, 100-102 cm. 

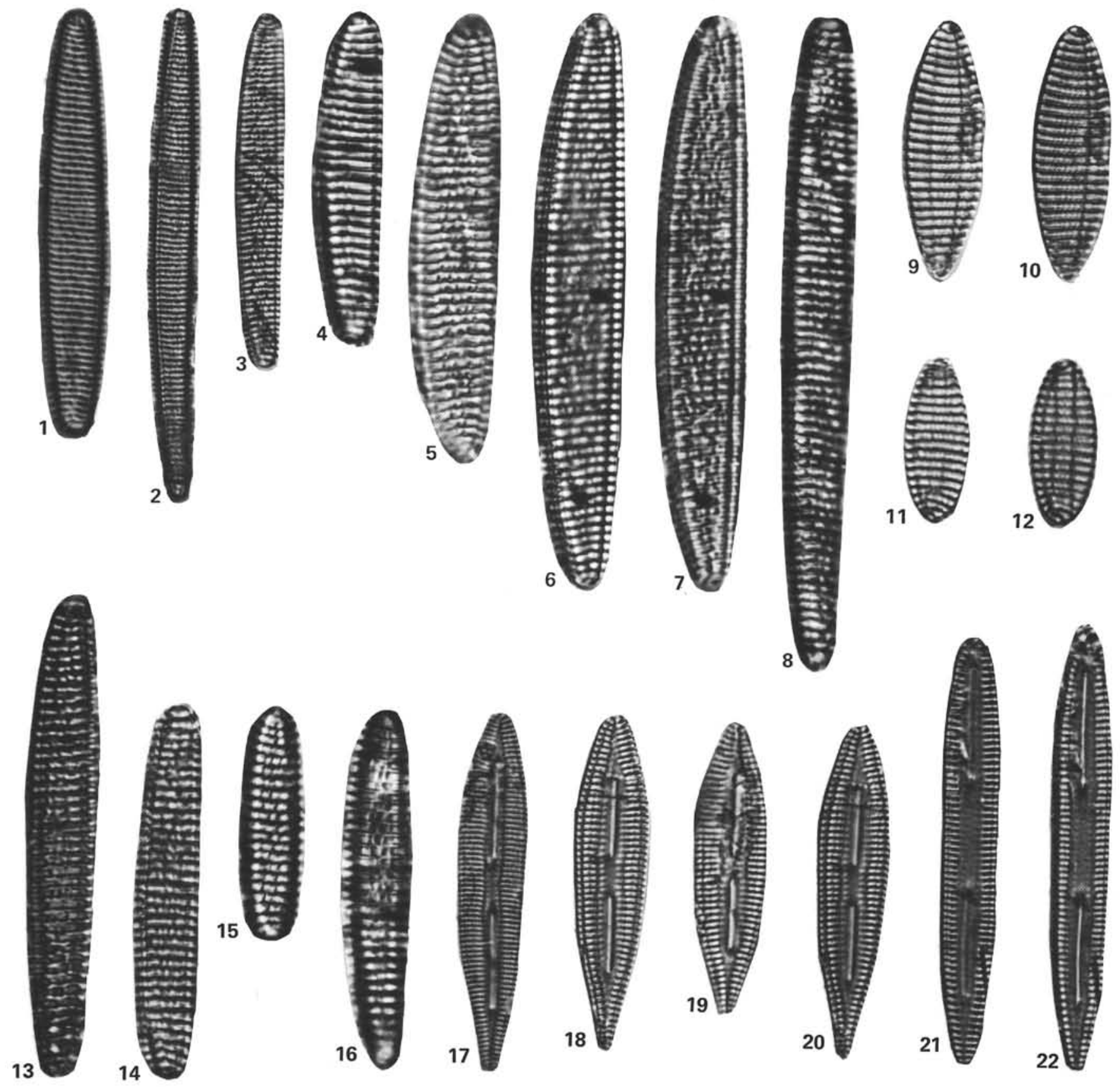

Plate 2. (All specimens magnified $\times 1500$ unless otherwise indicated.) $1-8$. Nitzschia praeinterfrigidaria $(1) \times 1000$, Sample $514-28-1,90-92 \mathrm{~cm}$, (2-4) Sample 514-34-2, 74-76 cm, (2-3, × 1000), (5) Sample 514-30-2, 66-68 cm, (6-7) Sample 514-31-3, 56-58 cm, (8) Sample 514-34-2, 66-68 $\mathrm{cm}$. 9-12. Nitzschia miocenica, Sample 513A-7-2, 57-59 cm. 13-16. Nitzschia praeinterfrigidaria (transitional to N. interfrigidaria), Sample 514-34-2, 74-76 cm. 17-20. Rouxia sp. 1, $\times 1000$, Sample 513A-5-5, 140-142 cm. 21-22. Rouxia sp. $2, \times 1000$, Sample 513A-4-7, 25-27 cm. 

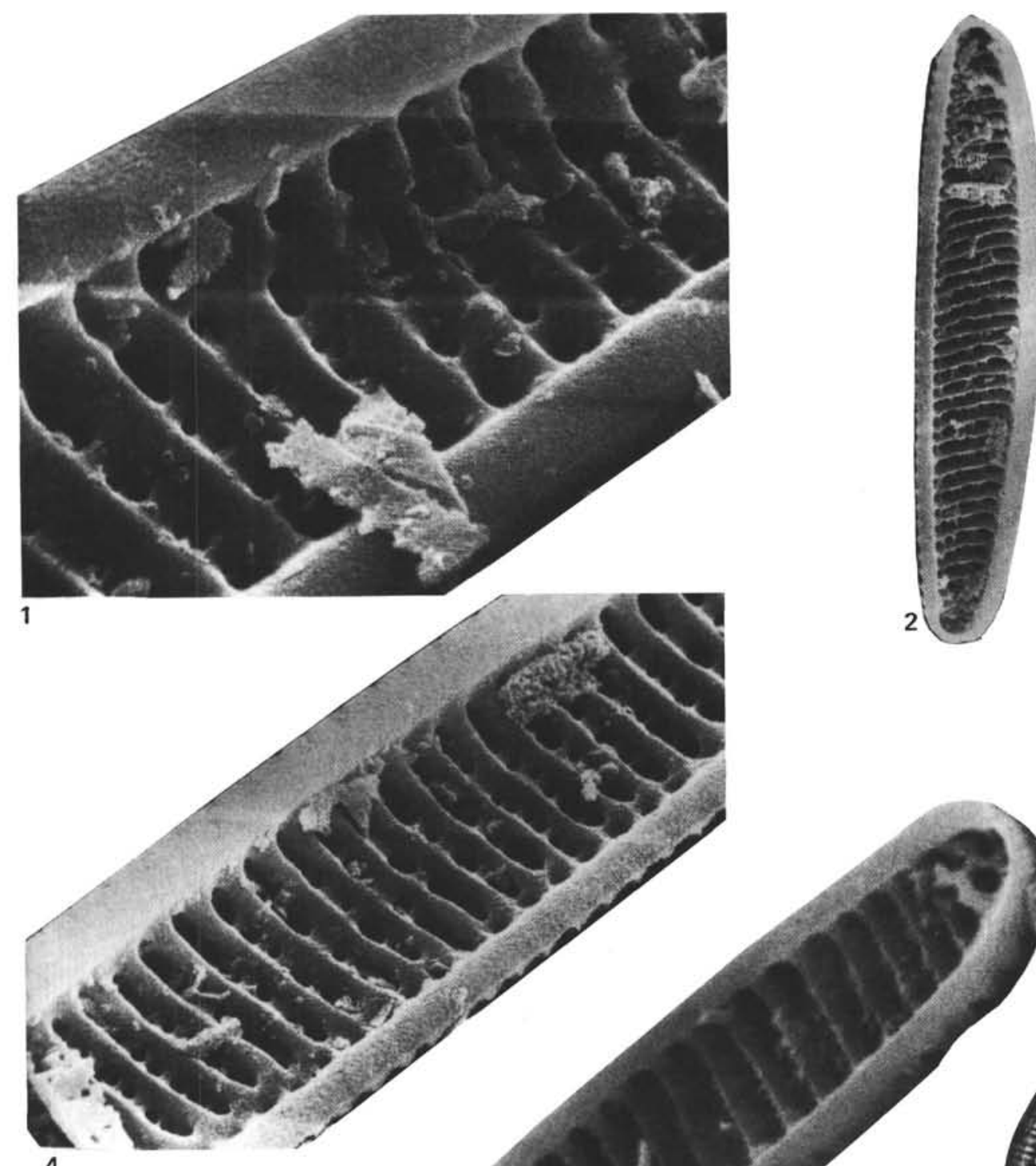

4
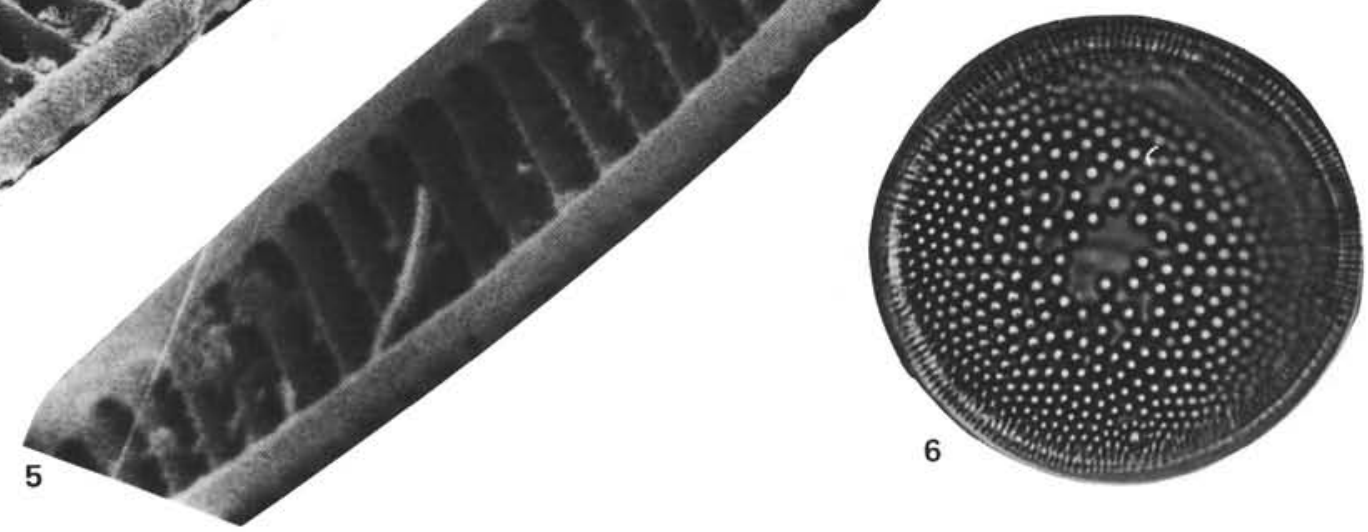

Plate 3. 1-4. Nitzschia cf. praeinterfrigidaria, SEM micrographs, Sample Eltanin 38-8, 320-322 cm, (1) $\times 10,000,(2) \times 2200,(3) \times 2000$, (4) $\times 5000$. 5. Nitzschia praeinterfrigidaria, SEM micrograph, Sample Eltanin $38-8,480-482 \mathrm{~cm}, \times 6000$. 6. Hemidiscus karstenii $\mathrm{f} .1$, $\times 800$, Sample 513A-5-3, 140-142 cm. 

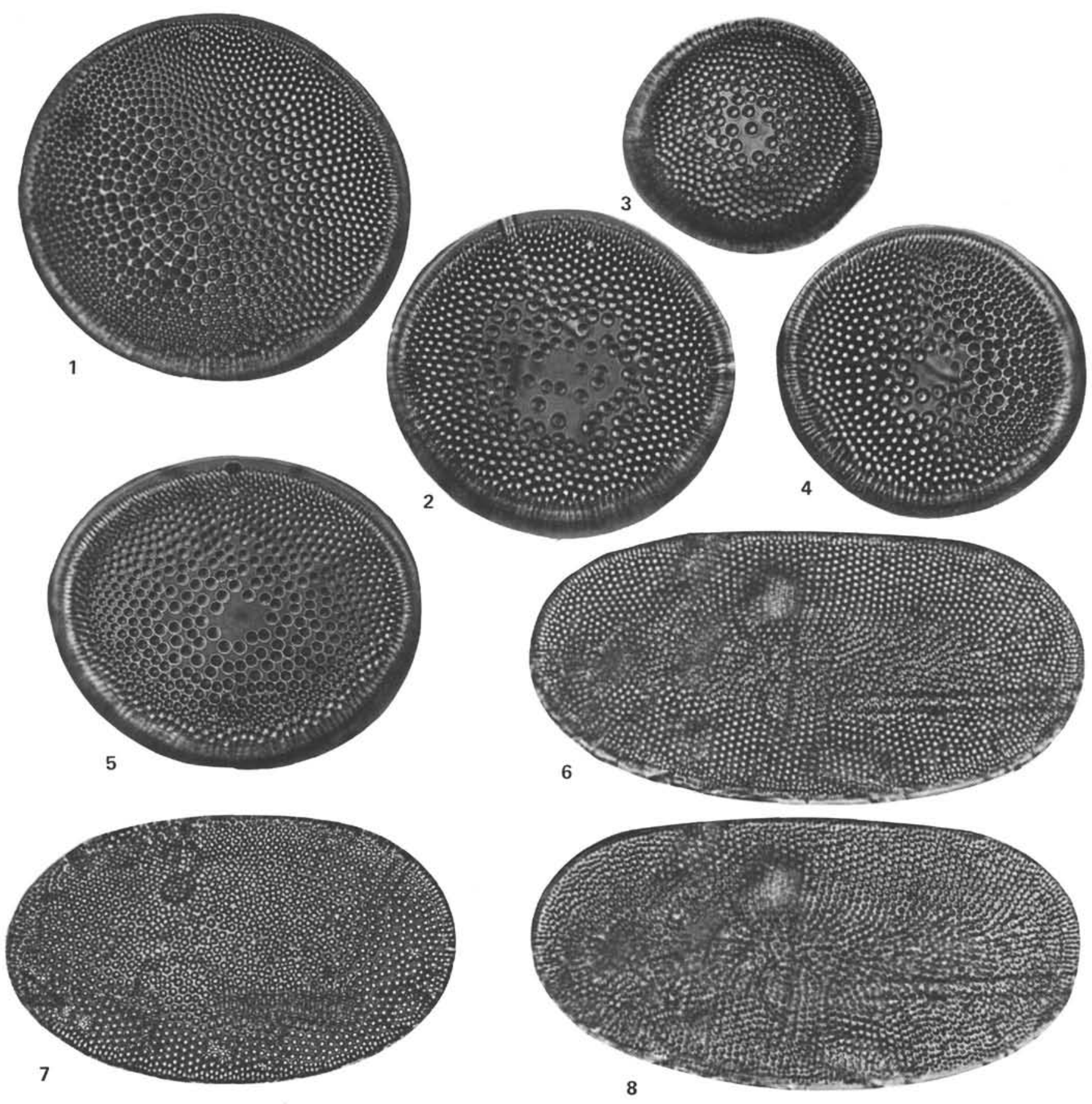

Plate 4. 1-5. Hemidiscus karstenii f. 1, ×800. (1-2, 4-5). Sample 513A-5-3, 140-142 cm, (3) Sample 513A-5-5, 140-142 cm. 6-8. Coscinodiscus lentiginosus f. obovatus $\mathrm{n}$. subsp., $\times 1000$, Sample $514-20-3,57-59 \mathrm{~cm},(7)$ holotype, $(6,8)$ paratype. 


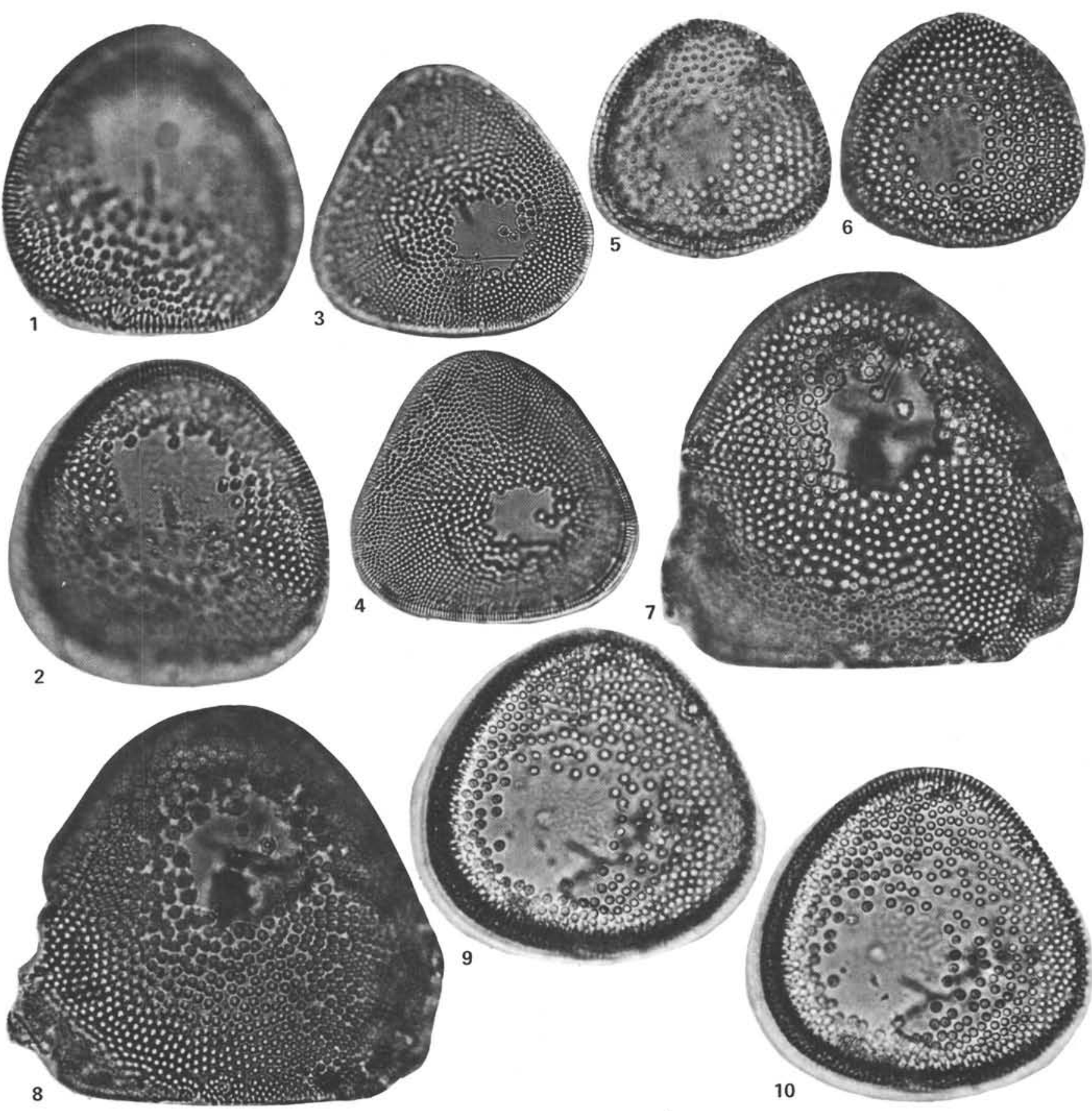

Plate 5. 1-10. Cosmiodiscus insignis $\mathrm{f}$. triangula, $(1-2,5-6) \times 1200$, Sample 513A-6-5, 140-142 cm, (3-4) $\times 600$, Sample 513A-6-7, 30-32 cm, (7-10) $\times 1000$, Sample 513A-6-5, 70-72 cm. 

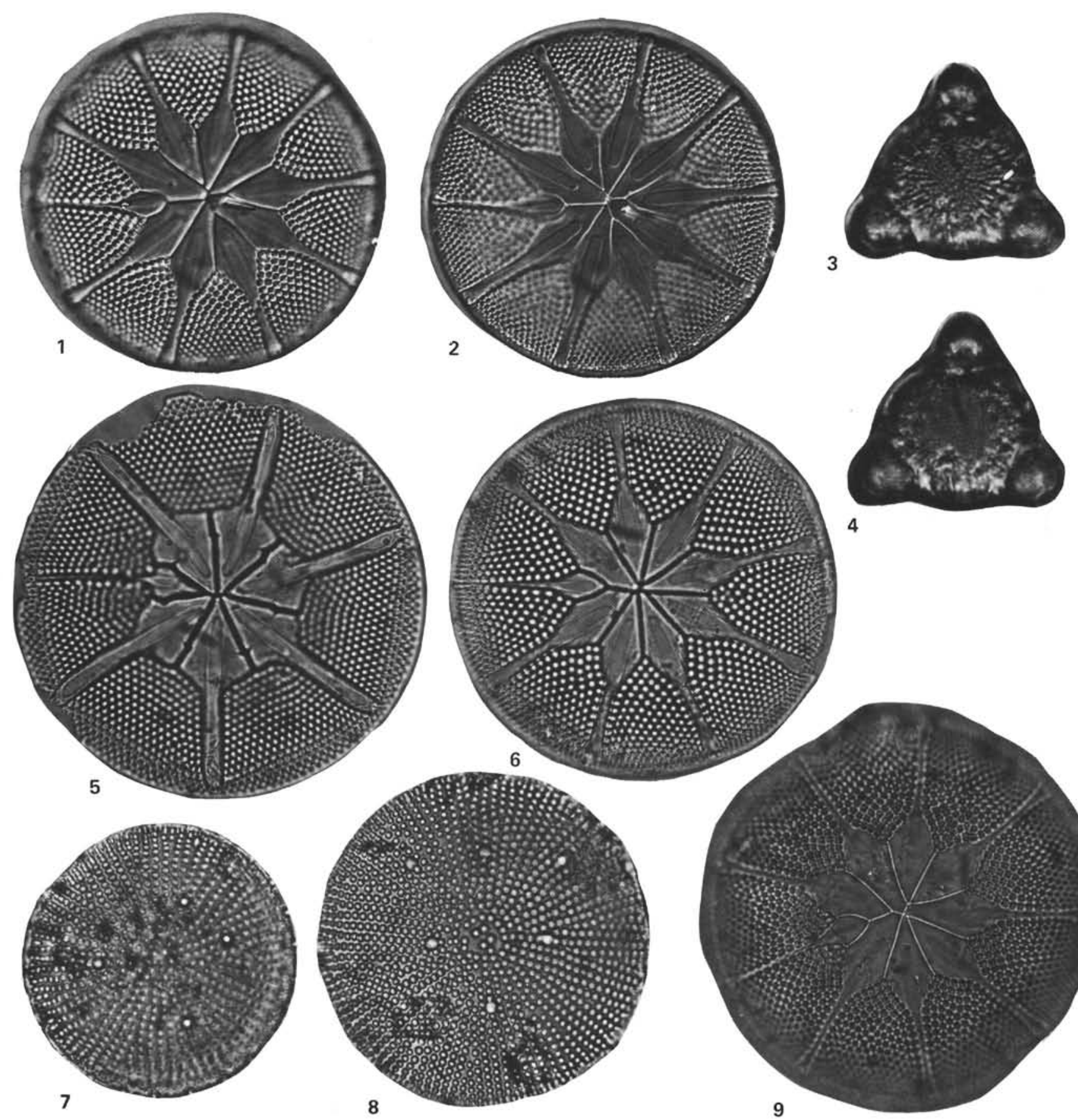

Plate 6. (All specimens magnified $\times 700$ unless otherwise indicated.) $1-2,6$, 9. Asteromphalus $\mathrm{sp} .1,(1-2)$ Sample $513 \mathrm{~A}-10-7,12-13 \mathrm{~cm},(6,9)$ Sample 513A-10-3, 70-72 cm. 5. Asteromphalus sp. 2, Sample 513A-6-7, 30-32 cm. 3-4. Lithodesmium cf. minusculum, Sample 513A-9-1, 69-71 cm. 7-8. Coscinodiscus vulnificus, $\times 1000$, (7) Sample 514-13-2, 49-50 cm, (8) Sample 513-6-5, 2-4 cm. 

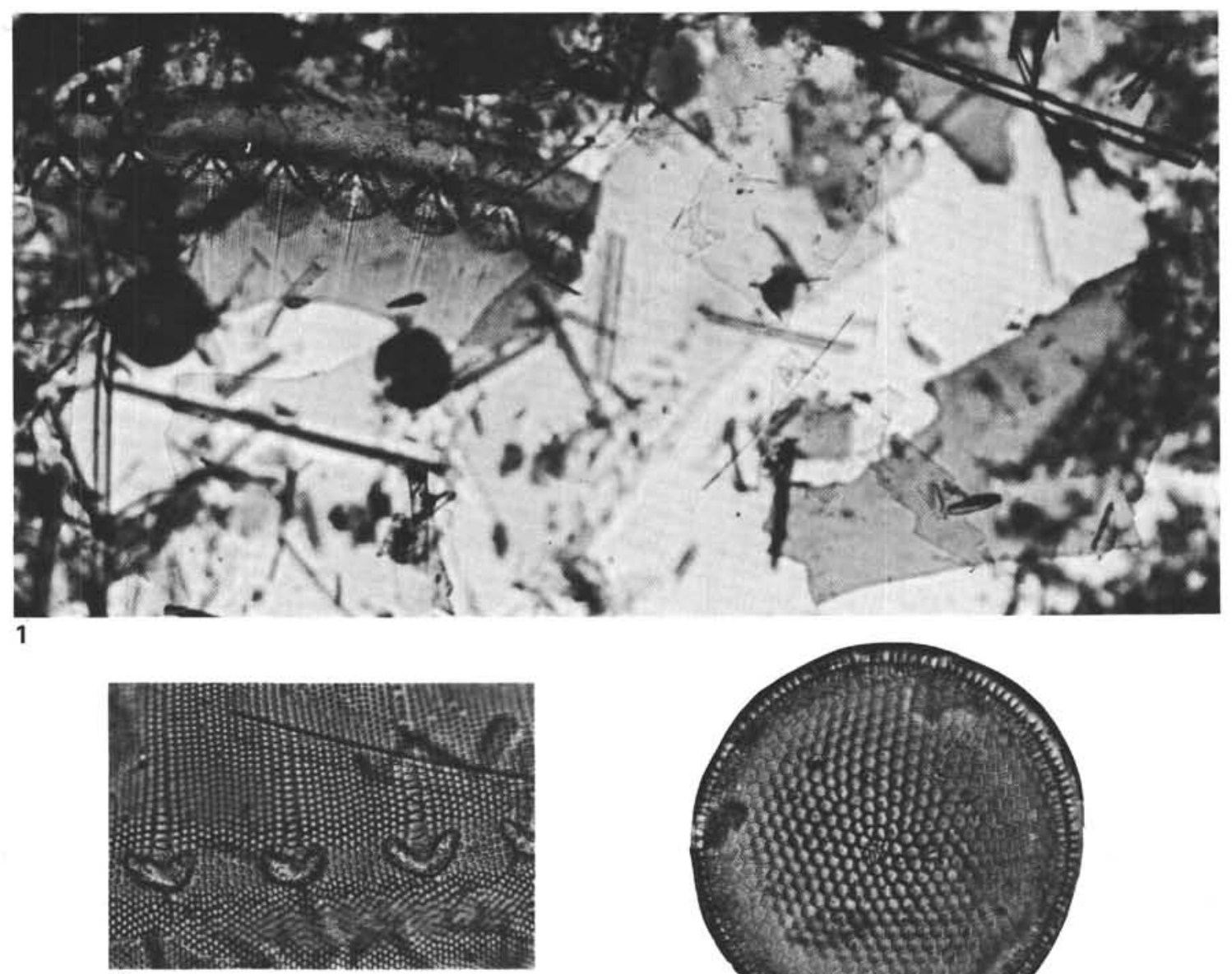

2
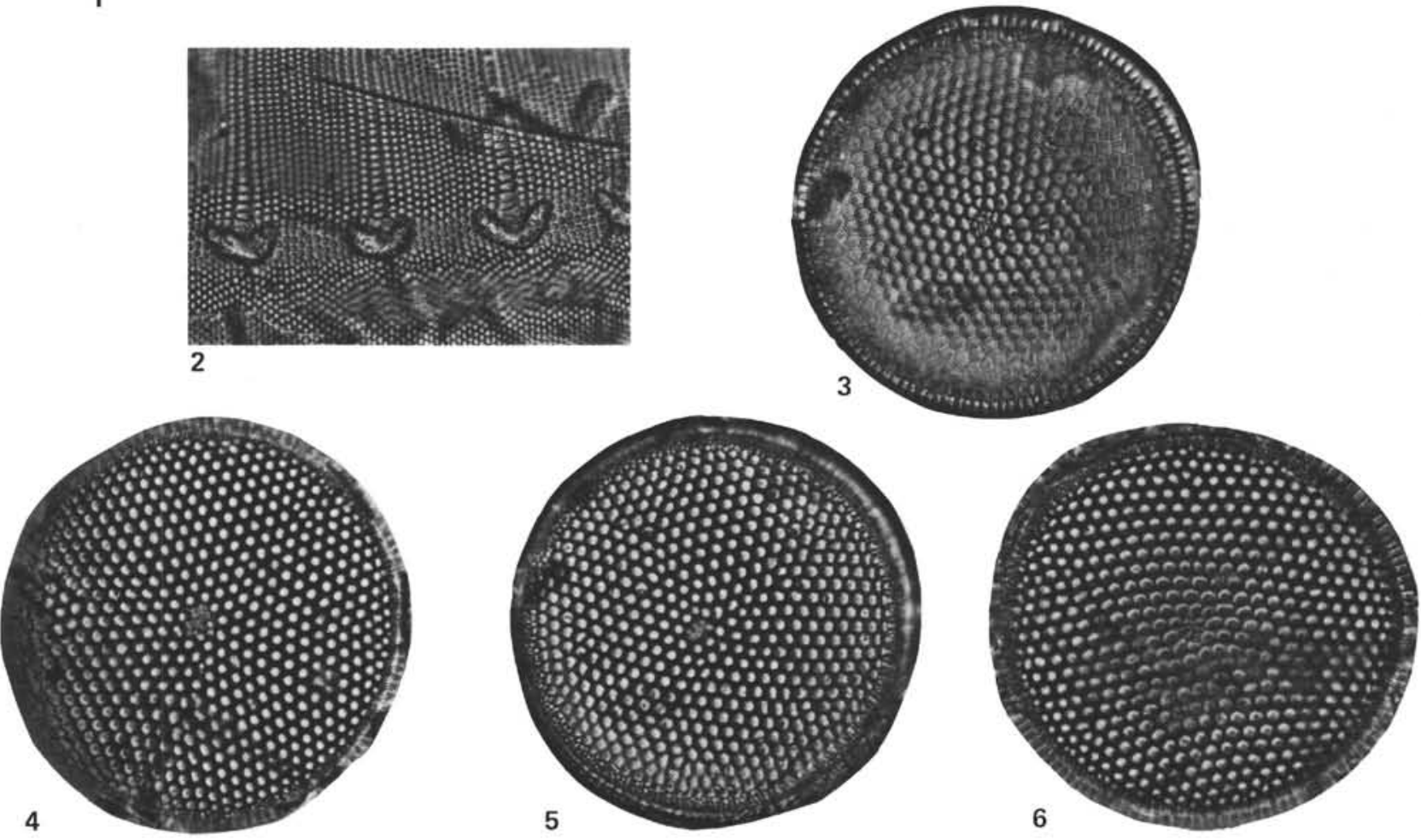

Plate 7. 1-2. Brunia mirabilis, Sample $512-2-2,96-98 \mathrm{~cm}$. (1) Field of view with large and small fragments of Brunia mirabilis, $\times 240$, (2) $\times 480$. 3-6. Thalassiosira torokina, $\times 600$, Sample $513 \mathrm{~A}-8-1,140-142 \mathrm{~cm}$. 